\title{
Parastenheliidae (Copepoda: Harpacticoida) from the Isles of Scilly
}

\author{
J. MICHAEL GEE
}

Plymouth Marine Laboratory, Prospect Place, Plymouth, UK

(Accepted 7 November 2006)

\begin{abstract}
Three species of Parastenheliidae were found at a sampling site around low tide level on St Martin's Flat in the Isles of Scilly. The most abundant species in the community was identified as Parastenhelia ornatissima but detailed study, particularly of the previously unknown male, indicates that this species has a sexually dimorphic antenna and belongs in the genus Karllangia as K. ornatissima comb. nov. Karllangia is re-diagnosed, $K$. tertia excluded from the genus; $K$. psammophila and $K$. bengalensis given specific status; Parastenhelia reducta placed incertae sedis in the genus and a key to species is provided. Five specimens (four being the previously undescribed male) of Parastenhelia anglica were found cooccurring with $K$. ornatissima. The species is redescribed; the P. anglica of Kunz from South Africa is shown to be the same as his Karllangia tertia and both these closely related species are placed in a new genus Foweya (as $F$. anglica comb. nov. and $F$. tertia comb. nov.) characterized by a sexually dimorphic inner spine on the P1 basis, no sexual dimorphism on the P3 endopod and the most primitive setal arrangement in the family. Also found at this site is Parastenhelia spinosa var bulbosa. This form has been raised to full specific status as $P$. bulbosa sp. nov. based on a detailed study of its anatomy which showed consistent differences with previous descriptions of $P$. spinosa from northwest Europe. It is suggested that, in the light of modern experimental, genetic and molecular techniques, the Langian concept of $P$. spinosa as a very variable, cosmopolitan species is probably erroneous and a thorough reappraisal of this species is needed.
\end{abstract}

Keywords: Karllangia, Parastenhelia, Foweya, Copepoda, Harpacticoida, Parastenheliidae, Scilly Isles

\section{Introduction}

During a study of the integral structure of a benthic infaunal assemblage at an apparently homogeneous site in the Isles of Scilly, Cornwall, England, a total of 464 species were identified, of which 75 were harpacticoid copepods (Warwick et al. 2006). The copepod assemblage was dominated by a species of Parastenheliidae which was three times more abundant than the next most dominant species, the Ameiridae Sicameira leptoderma Klie, 1950. The parastenheliid was originally identified as the very rare Parastenhelia ornatissima

Correspondence: J. Michael Gee, Plymouth Marine Laboratory, Prospect Place, The Hoe, Plymouth PL1 3DH, UK. Email: jmge@pml.ac.uk

Published 30 December 2006

ISSN 0022-2933 print/ISSN 1464-5262 online (C) 2006 Taylor \& Francis

DOI: $10.1080 / 00222930601108194$ 
(Monard) Lang, 1948 which was previously known only from a single female found in the Roscoff area of northern France. Two very rare species in the St Martins community also belonged in the Parastenheliidae, one identified as Parastenhelia anglica Norman and T. Scott, 1905 known only from two female specimens found off the Cornish coast and possibly a few specimens from South Africa. The other species was identified as Parastenhelia spinosa var. bulbosa (Bozic) Wells, 1963 known only from Roscoff, the Exe Estuary in Devon and the Scilly Isles.

Briefly, Thompson and A. Scott (1903) created the genus Parastenhelia Thompson and A. Scott, 1903 to accommodate a new species P. hornelli Thompson and A. Scott, 1903 from Ceylon. Previous to this Claus (1863) had described Thalestris forficula Claus, 1863 from the Mediterranean, whilst later Sars (1911) described Microthalestris littoralis Sars, 1911 and transferred Claus's species to the same genus. Lang (1934) made M. littoralis a subspecies of $M$. forficula, transferred both to the genus Parastenhelia along with $P$. hornelli, $P$. anglica and P. gracilis Brady, 1910 and placed the genus in the Thalestridae. Lang (1936) created a new sub-family, the Parastenheliinae, within the Thalestridae to accommodate Parastenhelia. Lang (1944) raised the sub-family to full family status, recognized that Harpacticus spinosus Fischer, 1860 belonged in Parastenhelia, so making $P$. spinosa (Fischer) Lang, 1944 the type species of the genus. Lang (1948) gave a full list of synonyms for $P$. spinosa and designated three forms of the species, forma typica (for $P$. forficula), forma littoralis, and forma penicillata (for the Microthalestris littoralis var. penicillata of Willey, 1935). Finally, Lang (1948) moved Thalestrella ornatissima Monard, 1935 into the genus as P. ornatissima. Since Lang's (1948) monograph, two new forms of $P$. spinosa and six new species have been added to the genus (see Bodin, 1997). Most recently, Willen (2000) moved the genus Karllangia Noodt, 1964 from the Ameiridae into the Parastenheliidae.

In this paper I give a detailed reappraisal of the three species of Parastenhelia from the Scilly Isles and conclude that $P$. ornatissima should be moved to the genus Karllangia; that $P$. anglica should be removed to a new genus, along with another species of Karllangia; that $P$. spinosa var. bulbosa should be raised to specific status and that the Langian concept of $P$. spinosa as a variable, cosmopolitan species should be questioned.

\section{Materials and methods}

Material from the Isles of Scilly was obtained from cores in clean coarse sand at LWST on St. Martin's Flats between the islands of St. Martin and Tresco. All sediments were sieved through a $63 \mu \mathrm{m}$ sieve and retained animals were fixed in $10 \%$, and preserved in $4 \%$, formalin. Before dissection, measurements of body length were made from whole specimens temporarily mounted in lactophenol. Specimens were dissected in lactophenol, the parts individually mounted in lactophenol under coverslips subsequently sealed with clear nail varnish. All drawings were prepared using a camera lucida on a Nikon Optiphot 20 differential interference contrast microscope. The terminology of the body and appendage morphology follows that of Huys and Boxshall (1991). Abbreviations used in the text and figures are P1-P6 for thoracopods $1-6$; $\exp (\operatorname{enp}) 1(2,3)$ to denote the proximal (middle, distal) segment of a ramus; benp denotes the baseoendopod of P5; and a for aesthetasc. Body length was measured from the base of the rostrum to the median posterior border of the anal somite. All material has been deposited in the Natural History Museum, London. 


\title{
Taxonomy
}

\author{
Family Parastenheliidae Lang, 1944
}

Genus Karllangia Noodt, 1964

\section{Diagnosis}

Parastenheliidae. Body small, usually with deeply divided ornamental hyaline frills. Rostrum, defined at base, triangular, reaching at most to end of second segment of antennule. Operculum semi-circular, variously ornamented. Caudal ramus with row(s) of spinules across dorsal surface and with seven elements. Female antennule eight- or indistinctly ninesegmented but with distal four or five segments small, combined length only slightly longer than segment 4. Male antennule eight-segmented, haplocer with three segments distal to geniculation, segment 5 moderately swollen. Female antenna with partially divided allobasis with a small pinnate seta on abexopodal margin; exopod two-segmented (or segments partially fused), proximal segment with two setae, distal segment with one lateral and two terminal setae; endopod with two subdistal spines and on distal margin one spine, four geniculate setae and two normal setae. Male antenna with enlarged, highly plumose seta on allobasis and exopod segments of different size with only one seta on proximal segment and all lateral setae enlarged and highly plumose. Mandibular basis with three setae, endopod one-segmented with eight setae, exopod usually present as a very small segment with two setae. Maxillule with slender elements on distal margin of praecoxal arthrite, two surface setae and two setae on inner margin; coxal endite with two to four setae and usually a seta representing the epipodite; basis and rami poorly chitinized, endopod present, exopod represented by one seta. Maxilla with three syncoxal endites with 3.2-3.2-3 elements, allobasal endite with three elements, endopod with four or five setae. Maxilliped syncoxa with one seta, basis oval with two setae on palmar margin, endopod a claw with one accessory seta. P1 exopod of three equal segments, exopod 2 with or without a small inner seta, distal segment with four elements (a naked seta, a geniculate spine and two outer spines, all spines strongly spinulous); endopod two-segmented, proximal segment about twice as long as exopod with inner seta implanted medially in a region of reduced chitinization of segment wall, distal segment small with one naked seta, a geniculate spine and a normal spine. P2-P4 rami three-segmented, exopod 1 without inner seta, setae on other segments well developed. Usually no sexual dimorphism in swimming legs but occasionally outer spine on P3 enp 3 in male reduced in size. Setal formula of exp/enp as follows: P2 0.1.223/1.1.121; P3 0.1.2-323/1.1.221; P4 0.1.323/1.1.221. Female P5 with triangular endopodal lobe with five setae and exopod two to five times longer than wide with five or six setae. Male P5 endopodal lobe with two setae, exopod with four setae.

Type species: Karllangia arenicola Noodt, 1964.

Other species: K. psammophila Wells, 1967, K. bengalensis Wells and Rao, 1987, K. pulchra Meilke, 1994, K. obscura Mielke, 1994, K. ornatissima (Monard) comb. nov.

Karllangia ornatissima (Monard) comb. nov.

(Figures 1-6)

\section{Synonyms}

Thalestrella ornatissima Monard 1935; Parastenhelia ornatissima (Monard) Lang 1948; Parastenhelia anglica Norman and T. Scott in Wells (1961). 


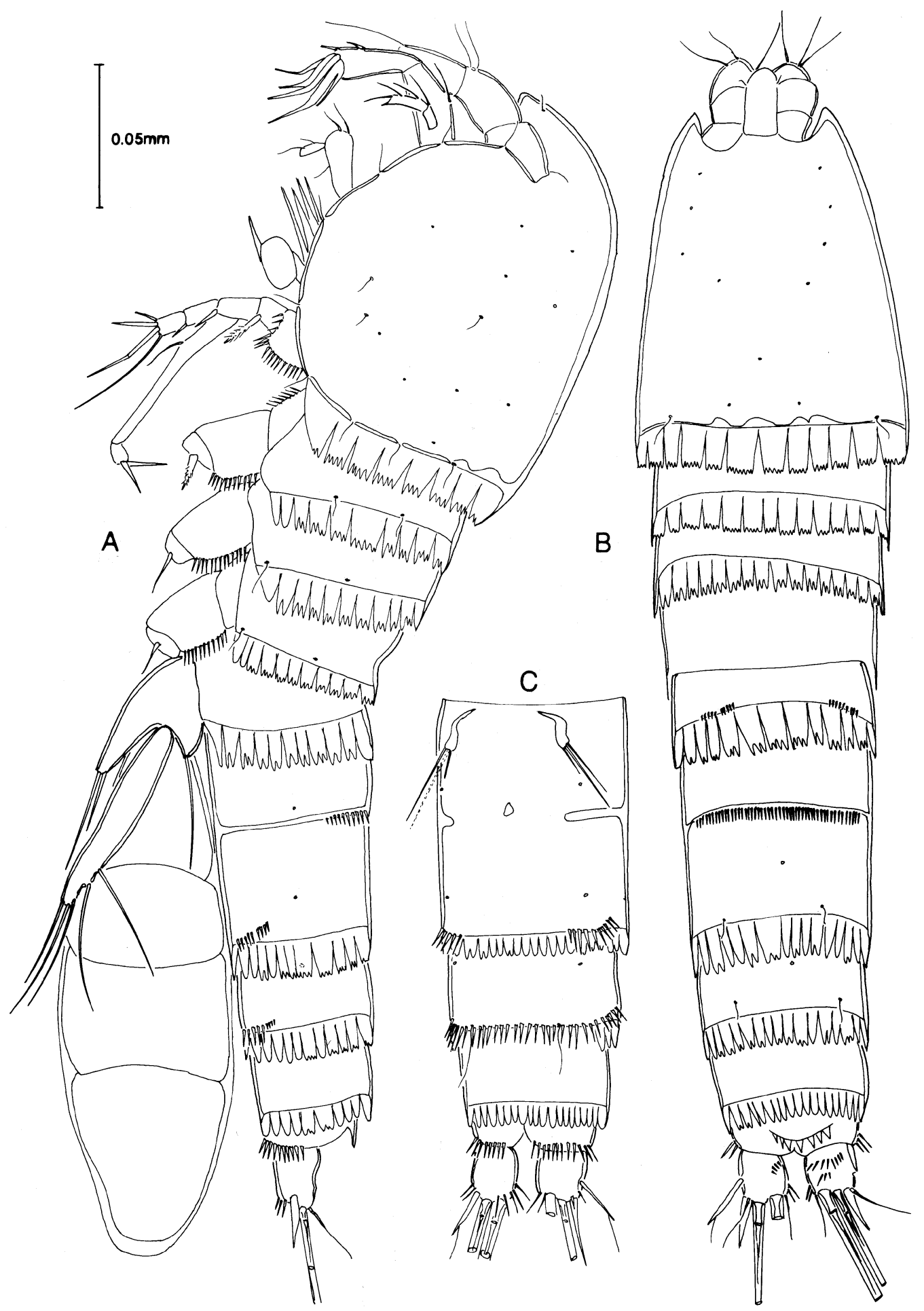

Figure 1. Karllangia ornatissima comb. nov. O habitus: (A) lateral view; (B) dorsal view; (C) ventral view of urosome, omitting P5-bearing somite. 


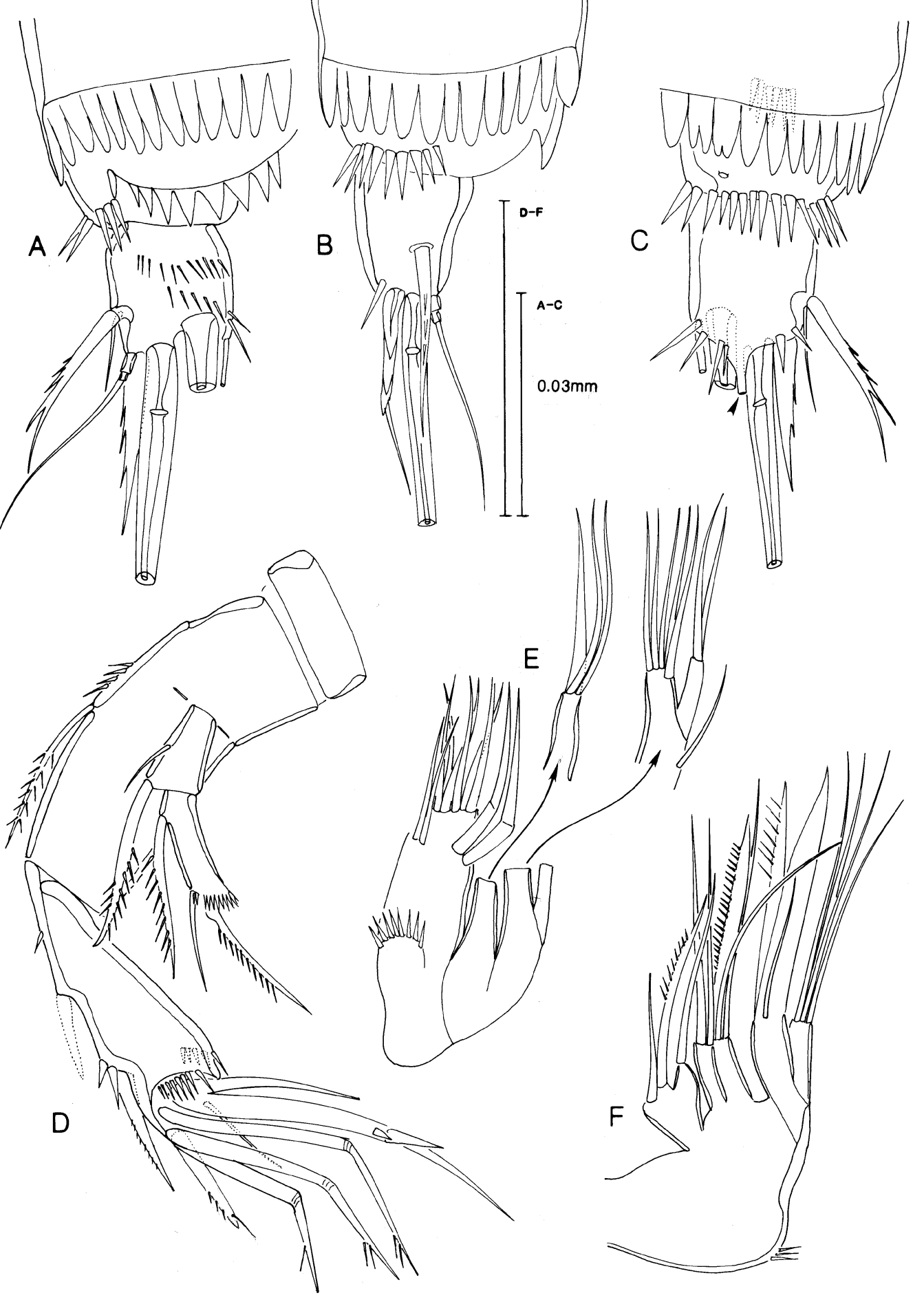

Figure 2. Karllangia ornatissima comb. nov. o operculum and caudal ramus: (A) dorsal view; (B) lateral view; (C) ventral view. Q: (D) antenna; (E) maxillule; (F) maxilla. 


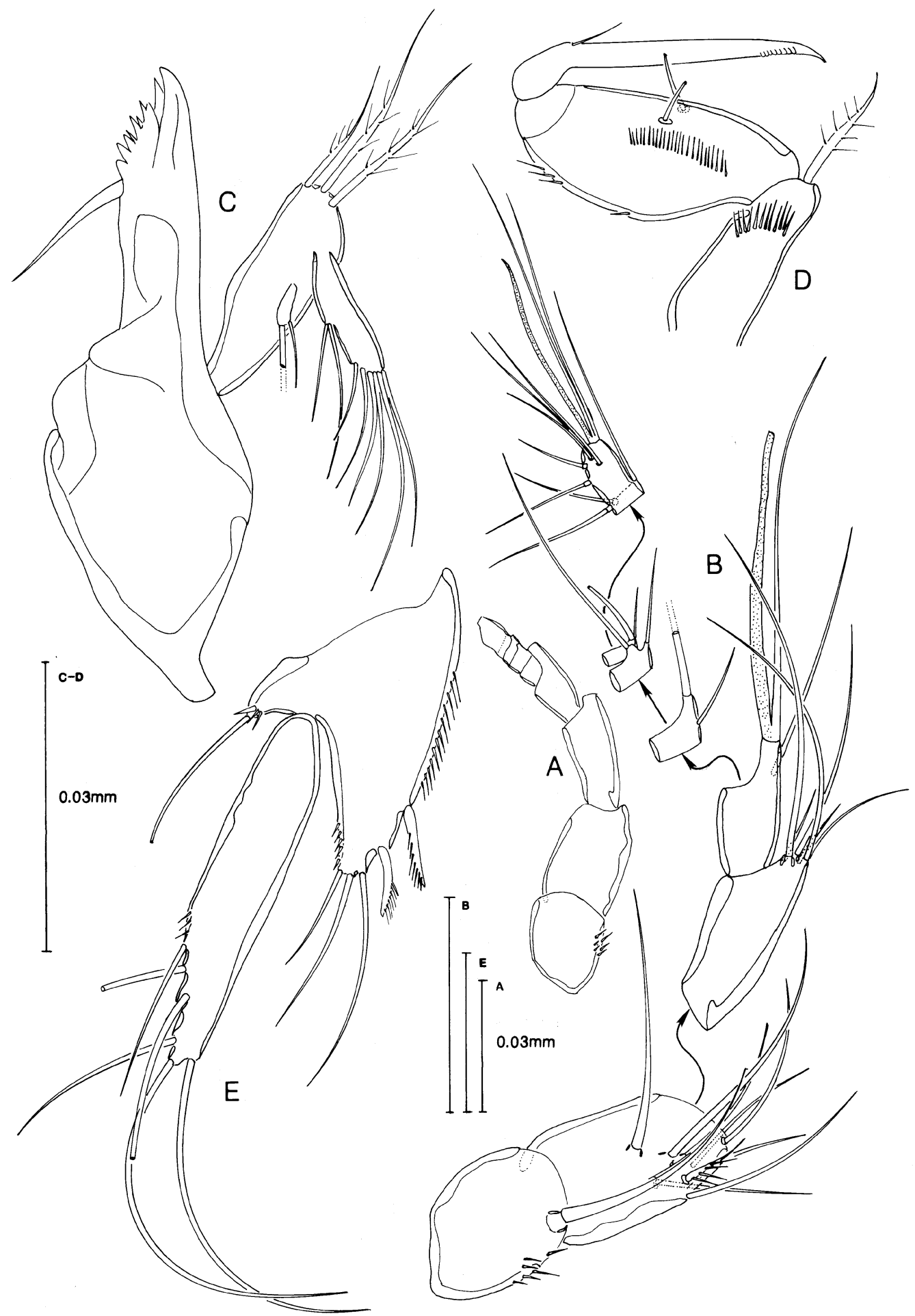

Figure 3. Karllangia ornatissima comb. nov. @: (A) antennule segmentation; (B) antennule armature; (C) mandible; (D) maxilliped; (E) P5. 

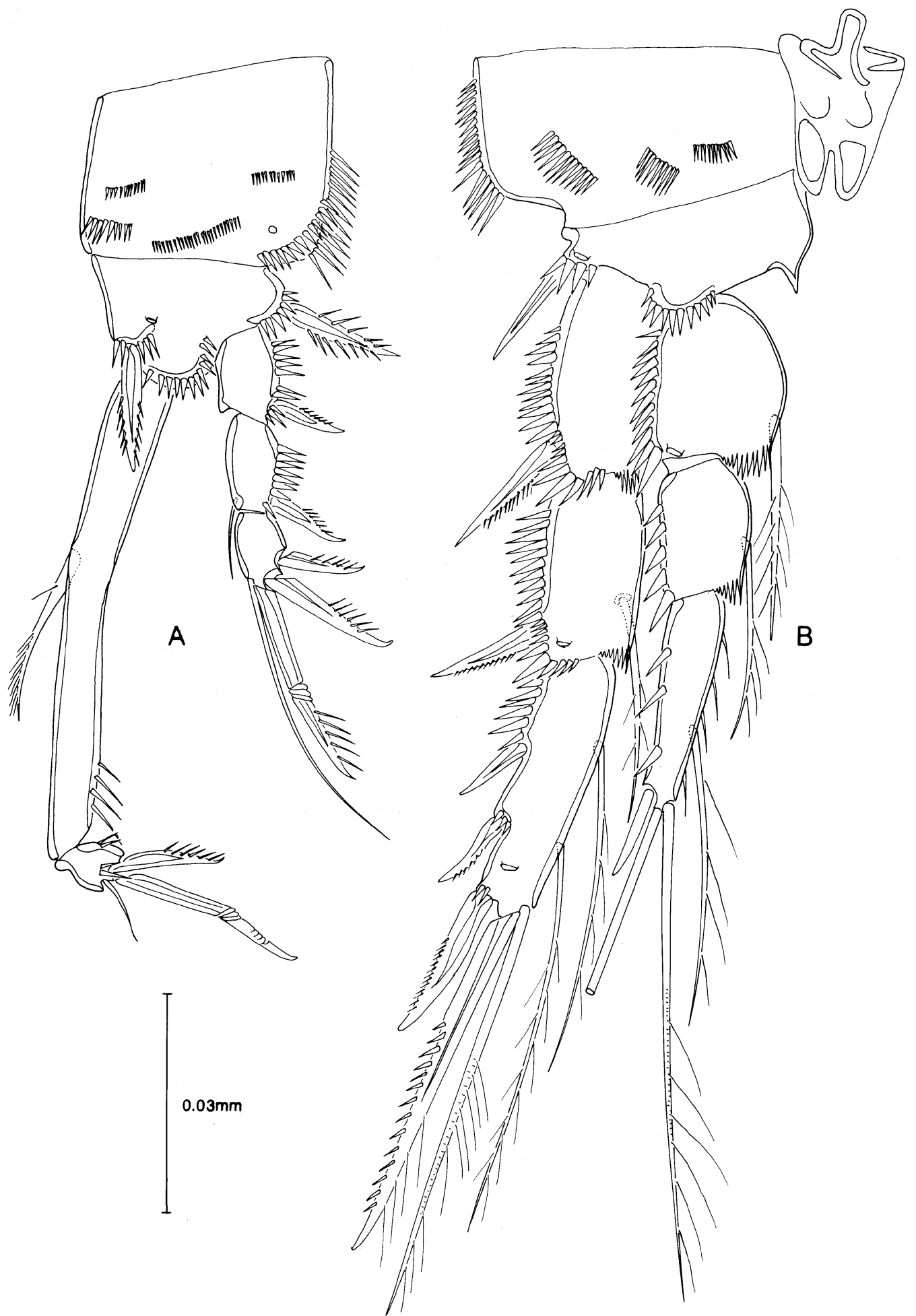

Figure 4. Karllangia ornatissima comb. nov. ọ: (A) P1; (B) P2. 


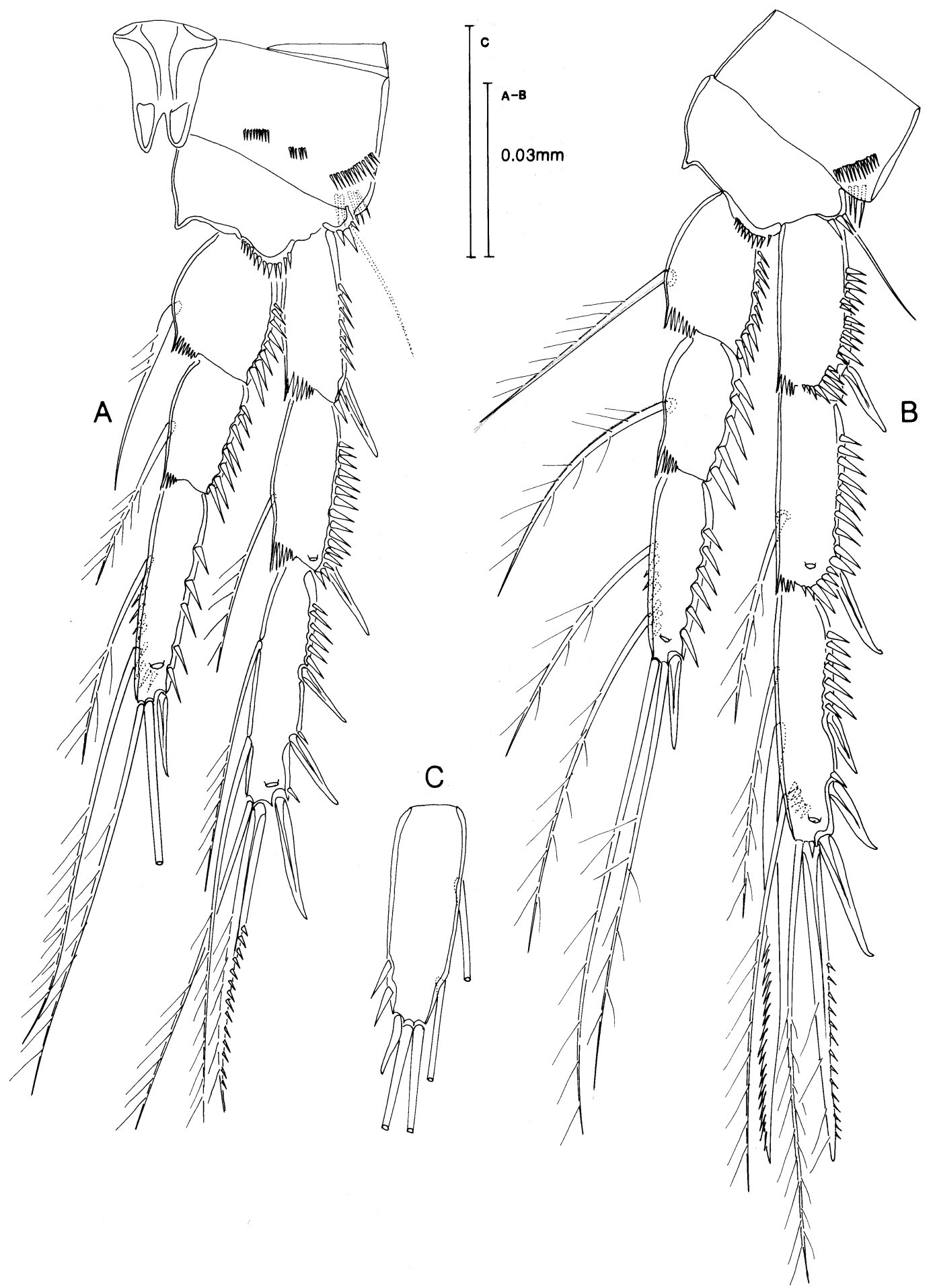

Figure 5. Karllangia ornatissima comb. nov. ํ: (A) P3; (B) P4. §̊: (C) P3 endopod 3. 


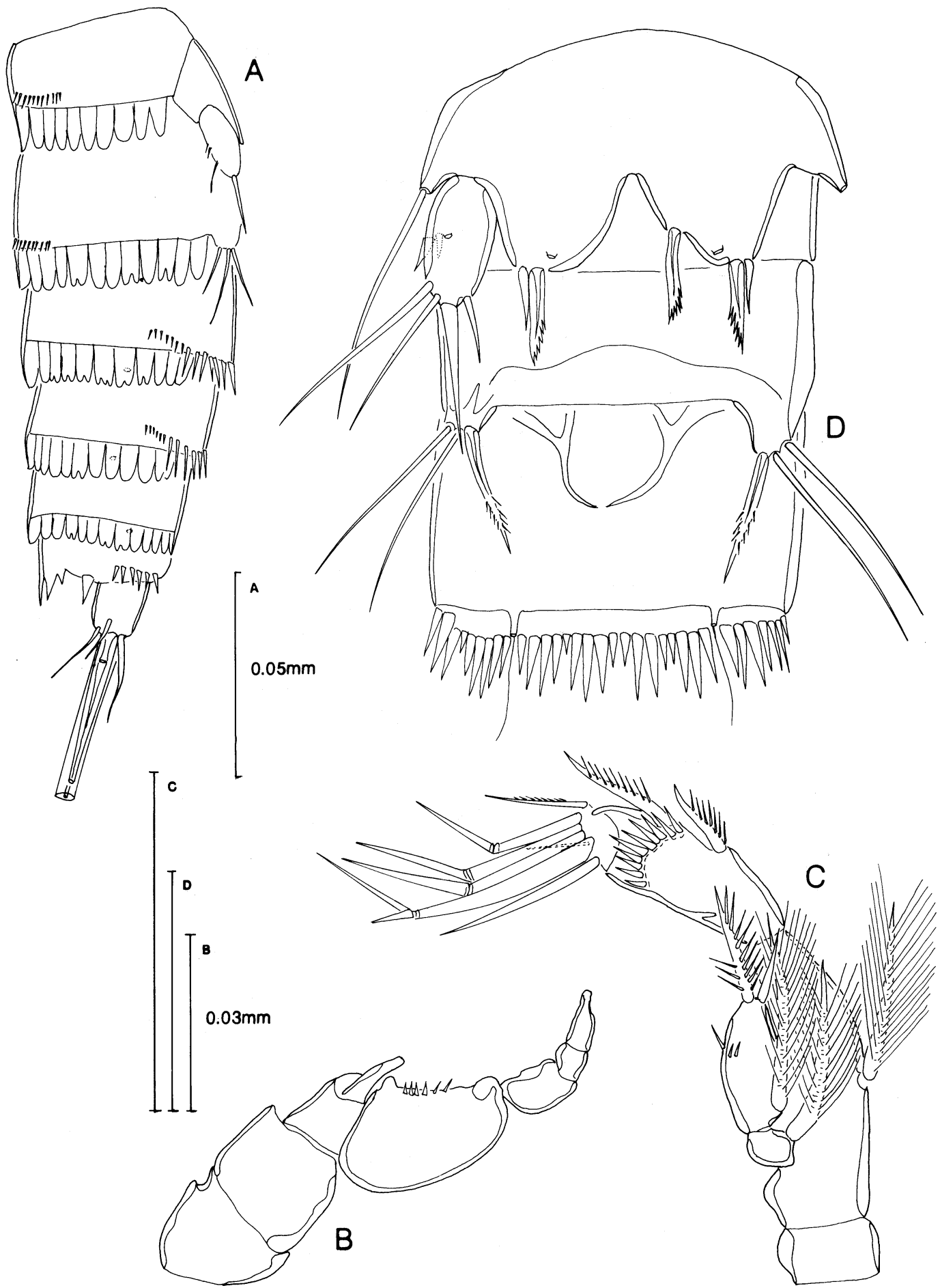

Figure 6. Karllangia ornatissima comb. nov. 3̊: (A) urosome, lateral view; (B) antennule segmentation; (C) antenna; (D) P5 and P6. 


\section{Material examined}

Neotype, 1 adult $q$, spirit preserved, NHM Reg. No. 2006.170. Paratypes, 2Q and 1 ○ิ (each dissected onto three slides), NHM Reg. Nos 2006.1971-1973 and 50o and 50 $\overbrace{}^{\hat{s}}$ spirit preserved, NHM Reg. Nos 2006.1974-1983

\section{Description of female}

Body (Figure 1). Length $0.315-0.46 \mathrm{~mm}$ (mean $0.37 \mathrm{~mm}, n=10$ ) semi-cylindrical, widest at posterior margin of cephalothorax, tapering gradually posteriorly and without clear distinction between prosome and urosome. Cephalothorax tapering anteriorly with welldeveloped pleural area and ornamented with pores and sensilla as in Figure 1. All prosomites with pronounced, deeply divided, serrate hyaline frill on dorsal and lateral posterior border. Urosomite 1 (P5-bearing somite) with two short rows of small spinules dorsally and a deeply divided hyaline frill on posterior border. Genital double somite with fusion line marked by dorsal and lateral sub-cuticular rib bearing a row of spinules dorsally; posterior margin of double somite with two short ventro-lateral spinule rows and a deeply divided hyaline frill. Genital apparatus (Figure 1C) consisting of median ventral copulatory pore and separate anterior gonopores each covered by a vestigial P6 bearing three setae. Urosomites 4 and 5 with deeply divided hyaline frill, former also with complete row of spinules on ventral posterior margin, latter without spinular ornamentation. Anal somite short, partially divided on posterior margin which bears a row of spinules ventrally at base of caudal rami. Anal operculum semi-circular, ornamented with six to eight coarse teeth (Figures 1B, 2A). Caudal rami (Figure 2A-C) about as long as broad with one or two diagonal rows of spinules on dorsal face and a row of spinules and a tube pore (arrowed in Figure 2C) on ventral posterior margin: bearing seven setae, antero-lateral seta I minute; setae II and III broad, spinulose with terminal flagellum; setae IV and V well developed, seta VI small and naked; triarticulate seta VII arising from dorsal outer distal corner of ramus.

Rostrum (Figure 1A,B). Well developed, reaching middle of segment 2 of antennule, defined at base, triangular with rounded tip and a pair of sub-apical sensilla.

Antennule (Figure 3A,B). Indistinctly nine-segmented (distal two segments partially fused), distal five segments small, combined length only slightly longer than segment 4 . Segment 1 with patch of spinules, segment 2 with a short pinnate seta; aesthetascs on segments 4 and 9. Setal formula as follows: 1-[1], 2-[9], 3-[6], 4-[1+(1+a)], 5-[2], 6-[2?], 7-[2?], 8-[3], 9$[5 ?+(2+a)]$.

Antenna (Figure 2D). With well-developed coxa. Allobasis partially divided with a pinnate seta and a row of spinules on abexopodal margin. Exopod of two approximately equal sized segments, proximal segment with two setae (a weak, naked proximal seta and a strong pinnate distal seta); distal segment with a distal dentate frill and three setae (strong pinnate setae on lateral and distal margin and a weak naked seta at outer distal corner). Endopod with row of spinules and two sub-distal spines on outer margin; distal margin with two rows of spinules and seven elements: a pinnate spine, four geniculate setae (inner with large pinnules at geniculation) and two plain setae, one of which is fused to base of inner geniculate seta. 
Mandible (Figure 3C). Coxal gnathobase well developed with bicuspid and unicuspid teeth and a seta at distal corner. Palp biramus, consisting of basis bearing three pinnate setae, an elongate one-segmented endopod with two lateral and six terminal setae and a small onesegmented exopod bearing two terminal setae.

Maxillule (Figure 2E). Small, poorly chitinized, particularly in region of basis and endopod, with setae closely bunched up and difficult to discern. Praecoxal arthrite with a proximal row of spinules, with three pairs of slender elements on distal margin, two geniculate surface setae and two setae on inner margin. Coxal endite with three (or four) setae on distal margin (and possibly an epipodite represented by one seta which could not be discerned in these dissected specimens). Basis with five setae; endopod one-segmented with two setae; exopod represented by one seta.

Maxilla (Figure 2F). Small, difficult to make out exact setation. Bears three coxal endites, proximal endite broad and bicuspid with two setae (one pinnate) on inner cusp and one or two seta(e) on outer cusp; middle endite with two setae, outer endite with three setae (one broad and pinnate); allobasal endite with one fused spine, one articulating, pinnate, spine and one or two naked setae; endopod with four setae.

Maxilliped (Figure 3D). Syncoxa with row of spinules and one pinnate seta on distal margin. Basis with row of spinules on outer margin and on each lateral face, bearing two small setae near palmar margin. Endopod represented by a well-developed claw with small teeth on distal inner margin and one accessory seta proximally.

P1 (Figure 4A). Intercoxal sclerite (not illustrated) small, oval, unadorned. Coxa almost square with a row of setules on outer margin, a row of spinules and a pore at the outer distal corner and four rows of small spinules on anterior face. Basis with rows of spinules on median distal margin and at base of inner and outer stout pinnate spines, a pore also at base of inner spine. Exopod of three more or less equal-sized segments; proximal and middle segments with row of spinules on outer margin and a spine at outer distal corner; middle segment with a very small, weak seta which in most cases lies along the posterior face of the ramus and is only visible under x100 oil immersion; distal segment bearing a slender naked seta and a spinulous geniculate spine on distal margin and two spinulose, non-geniculate spines on outer margin. Endopod two-segmented; proximal segment elongate, about twice as long as exopod, with a few spinules on outer distal margin; at mid-point of segment the chitinous segment wall is noticeably thinner and at same point arises a stout inner seta with a plumose distal portion; distal segment small, bearing a very small naked seta, a geniculate spine and a spinulose spine.

P2-P4 (Figures 4B, 5A, B). Intercoxal sclerite unadorned; praecoxa small; coxa with row of spinules on outer margin and two or three rows of spinules on anterior face; basis with row of spinules on median distal margin and at base of outer element which is a naked spine on P2 and a naked seta on P3 and P4. Both rami three-segmented, all segments with row of spinules on outer margin; exp 2 and 3, enp 1 in P2 and enp 3 in P3-P4 with pore on anterior face; exp 1 without an inner seta but all setae on other segments well developed, distal outer element on exp 3 a pinnate spine and middle inner seta on P4 exp 3 strongly developed with a serrate margin. Setal formula of swimming legs as follows: 


$\begin{array}{llc} & \text { Exopod } & \text { Endopod } \\ \text { P1 } & 0.1 .022 & 1.111 \\ \text { P2 } & 0.1 .223 & 1.1 .121 \\ \text { P3 } & 0.1 .223 & 1.1 .221 \\ \text { P4 } & 0.1 .323 & 1.1 .221\end{array}$

P5 (Figure 3E). Benps of each side not fused medially and exopods also separate. Benp with well-developed inner expansion triangular in shape with row of spinules on median inner margin and distal outer margin and bearing five elements, two short pinnate spines on inner margin and three naked setae on distal margin. Outer basal peduncle of benp with a few spinules and a naked seta. Exopod slender, five times longer than wide, bearing six naked setae, two on distal margin and four on outer margin.

\section{Description of male}

As in female except for urosome, antennule, antenna, P5 and P6.

Body. Slightly smaller than female, length $0.258-0.4 \mathrm{~mm}$ (mean $0.302 \mathrm{~mm}, n=10$ ) and urosomites 2 and 3 not fused (Figure 6A). Body ornamentation as in female except that ventral row of spinules on urosomite 3 complete (Figure 6D).

Antennule (Figure 6B). Eight-segmented, haplocer, with moderately swollen segment 5 with row of spinules and aesthetasc, acrothek of two setae and small aesthetasc on distal segment. All setae naked except a small pinnate seta on segment 2. Setal formula tentatively given as follows although some setae may be missing:- 1-[1], 2-[11], 3[4?], 4\{2?], 5$[8 ?+(1+a)], 6[1+2$ modified spines $], 7[4], 8-[7 ?+(2+a)]$.

Antenna (Figure 6C). Allobasis with enlarged and highly plumose seta on abexopodal margin. Exopod two-segmented but proximal segment reduced in size and bearing only one element, a large highly plumose seta; distal segment swollen, with proximal seta swollen and highly plumose and two setae on distal margin more strongly developed. Subdistal spines on outer margin of endopod more strongly spinulose.

P5 (Figure 6D). Benps of each side fused medially, inner expansions more rounded and bearing two elements, a small serrate spine and a smaller naked spine. Exopod only twice as long as wide, ovoid with short row of spinules on outer margin and four naked setae (note figured specimen shows an aberrant setal arrangement on one baseoendopodal lobe).

P6 (Figure 6D). A single plate with one pinnate and two naked setae on a small extension on each side.

Genus Foweya gen. nov.

Synonyms

Parastenhelia (part); Karllangia (part). 


\section{Diagnosis}

Parastenheliidae. Body with faint, deeply divided, hyaline frills. Rostrum, defined at base, triangular, reaching at most to end of second segment of antennule. Operculum semicircular, variously ornamented. Caudal ramus with row(s) of spinules across dorsal surface and with seven elements. Female antennule nine-segmented, distal five segments with a combined length greater than that of segment 4. Male antennule 10-segmented, haplocer with three segments distal to geniculation, segments 5-7 moderately swollen. Antenna with partially divided allobasis with a pinnate seta on abexopodal margin; exopod twosegmented, proximal segment with two setae, distal segment with two lateral and three terminal setae; endopod with two subdistal spines and on distal margin one spine, four geniculate setae and two normal setae. Mandibular basis with three setae, endopod onesegmented with eight setae, exopod one-segmented with four setae. Maxillule with slender elements on distal margin of praecoxal arthrite, two surface setae and three setae on inner margin; coxal endite with six setae and an epipodite represented by one seta; endopod poorly chitinized, exopod present bearing two setae. Maxilla with three syncoxal endites with 4.3.3 elements, allobasal endite with four elements, endopod with four or five setae. Maxillipedal syncoxa with three setae, basis oval with two setae on palmar margin, endopod a claw with two accessory setae. P1 basis inner seta sexually dimorphic (bifid tip in male), exopod three-segmented, exp 2 only slightly longer than exp 1, with an inner seta, distal segment small, with a naked seta, a geniculate spine and two outer spines, all spines strongly spinulous; endopod two-segmented, proximal segment about twice as long as exopod with inner seta implanted at $35 \%$ of ramus length in a region of reduced chitinization of segment wall, distal segment small with one naked seta and two pinnate spines. P2-P4 rami three-segmented, except male P2 endopod sometimes two-segmented as result of fusion of middle and distal segments, no sexual dimorphism in P3 endopod: setal formula of exp/enp as follows: P2 1.1.223/1.1.221; P3 1.1.323/1.1.321; P4 1.1.323/ 1.1.221. Female P5 endopodal lobe with five setae, exopod about three times longer than wide with six setae. Male P5 endopodal lobe with two setae, exopod with five or six setae.

Type species: Foweya anglica (Norman and T. Scott) comb. nov.

Other species: Foweya tertia (Kunz) comb. nov.

\section{Etymology}

Fowey (pronounced Foy) is the Cornish port that is the type locality of the genus.

Foweya anglica (Norman and T. Scott) comb. nov.

(Figures 7-11)

Synonyms

Parastenhelia anglica Norman and T. Scott, 1905.

\section{Material examined}

Holotype, 1 o, dissected onto one slide, collected by Norman at Fowey, Cornwall, NHM Reg. No. 1911.11.8.M.2423.371. Paratype, 1Q (spirit preserved) in Norman Collection NHM Reg. No. 1911.11.8.43325. Other material from St. Martins Flat, Isles of Scilly, 1o 


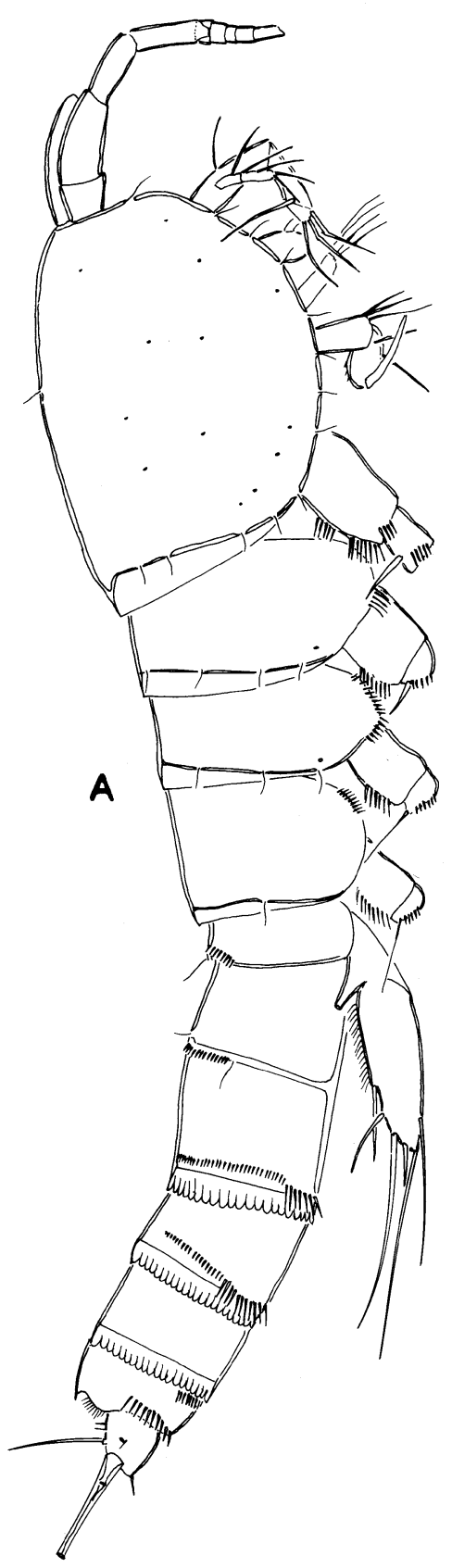

$T^{A}$
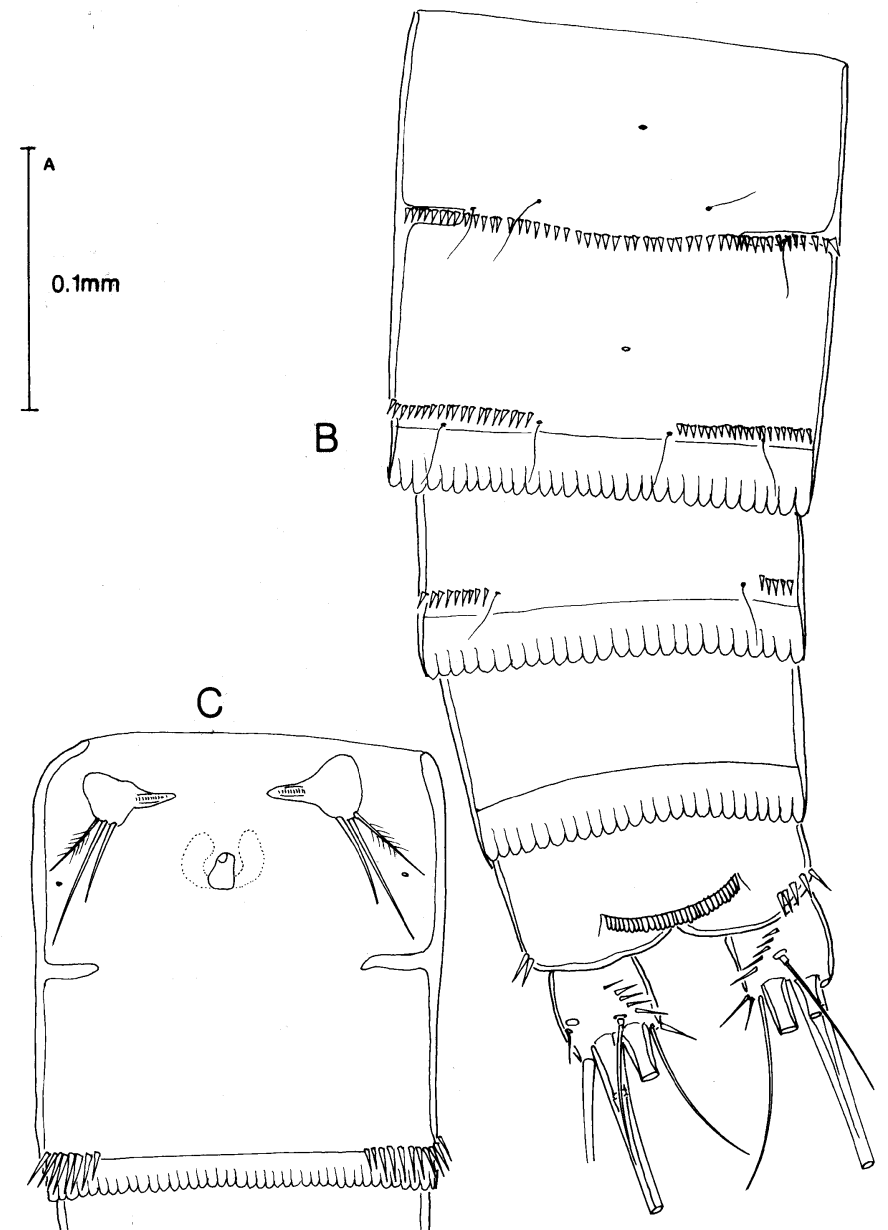

Figure 7. Foweya anglica comb. nov. థ habitus: (A) lateral view. ९ urosome, omitting P5 bearing somite: (B) dorsal view; (C) ventral view. 

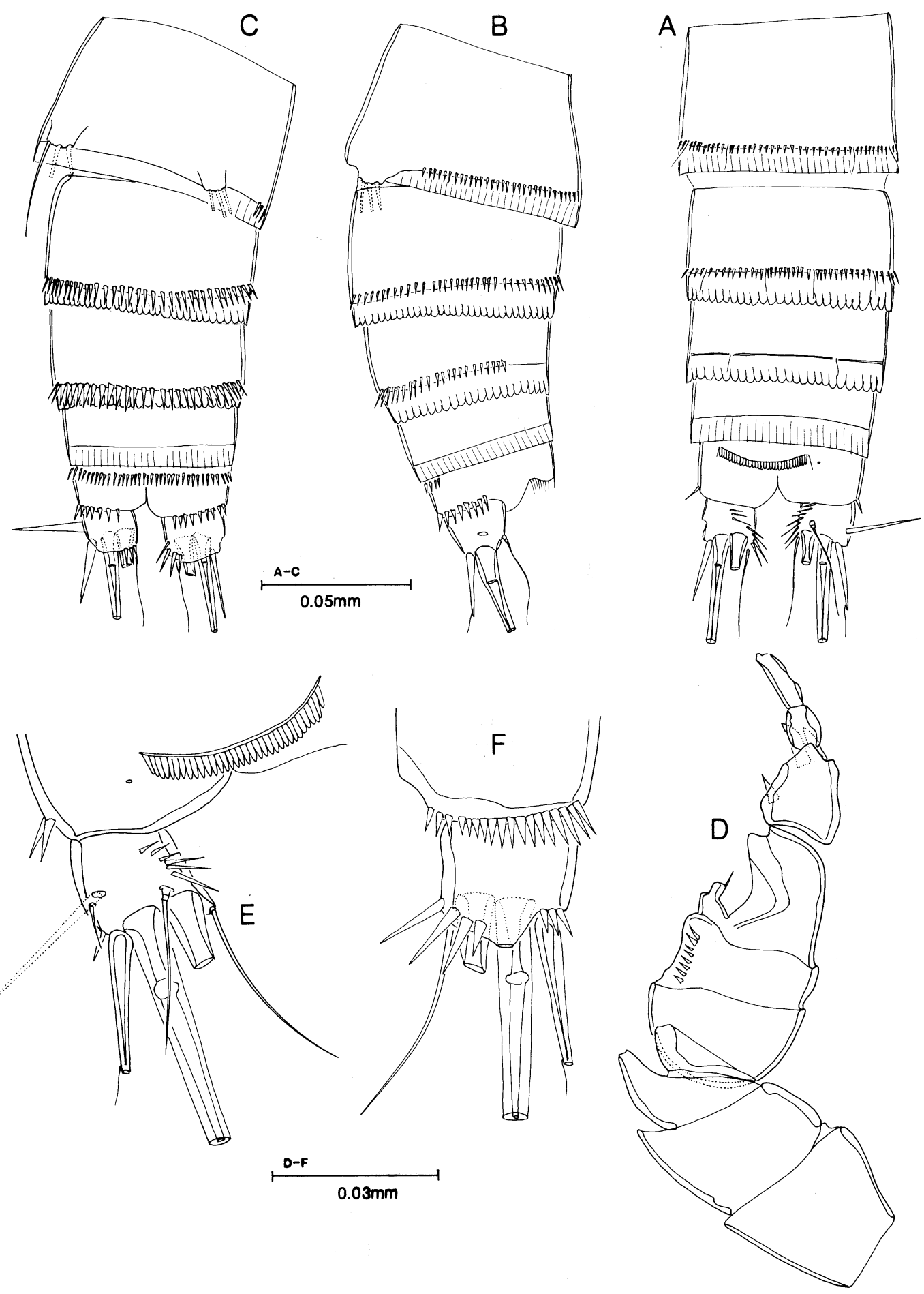

Figure 8. Foweya anglica comb. nov. ô urosome (excluding P5 bearing somite): (A) dorsal view; (B) lateral view; (C) ventral view; (D) Antennule segmentation. @ operculum and caudal ramus: (E) dorsal view; (F) ventral view. 


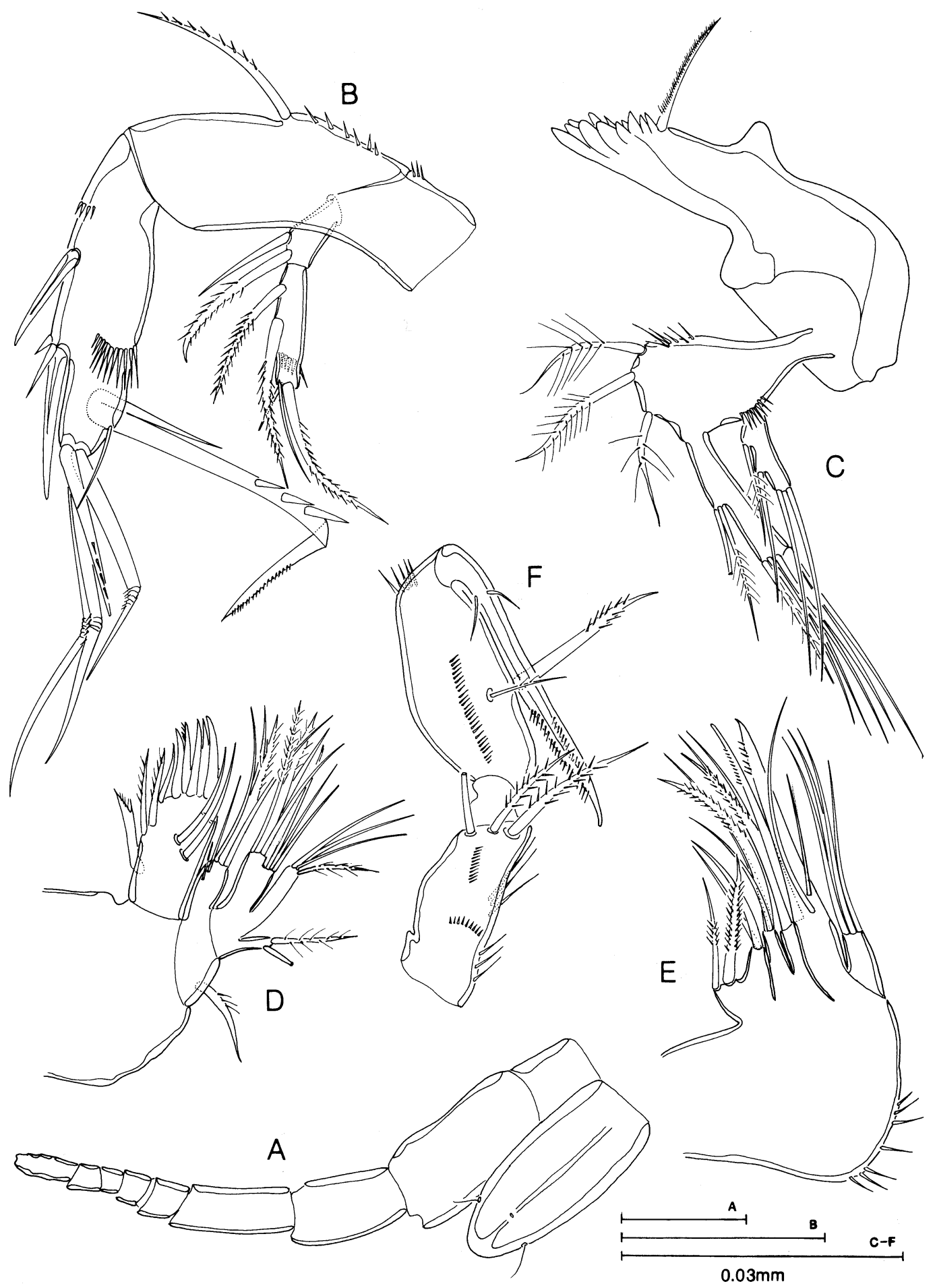

Figure 9. Foweya anglica comb. nov. ọ: (A) Antennule segmentation; (B) antenna; (C) mandible; (D) maxillule; (E) maxilla; (F) maxilliped. 


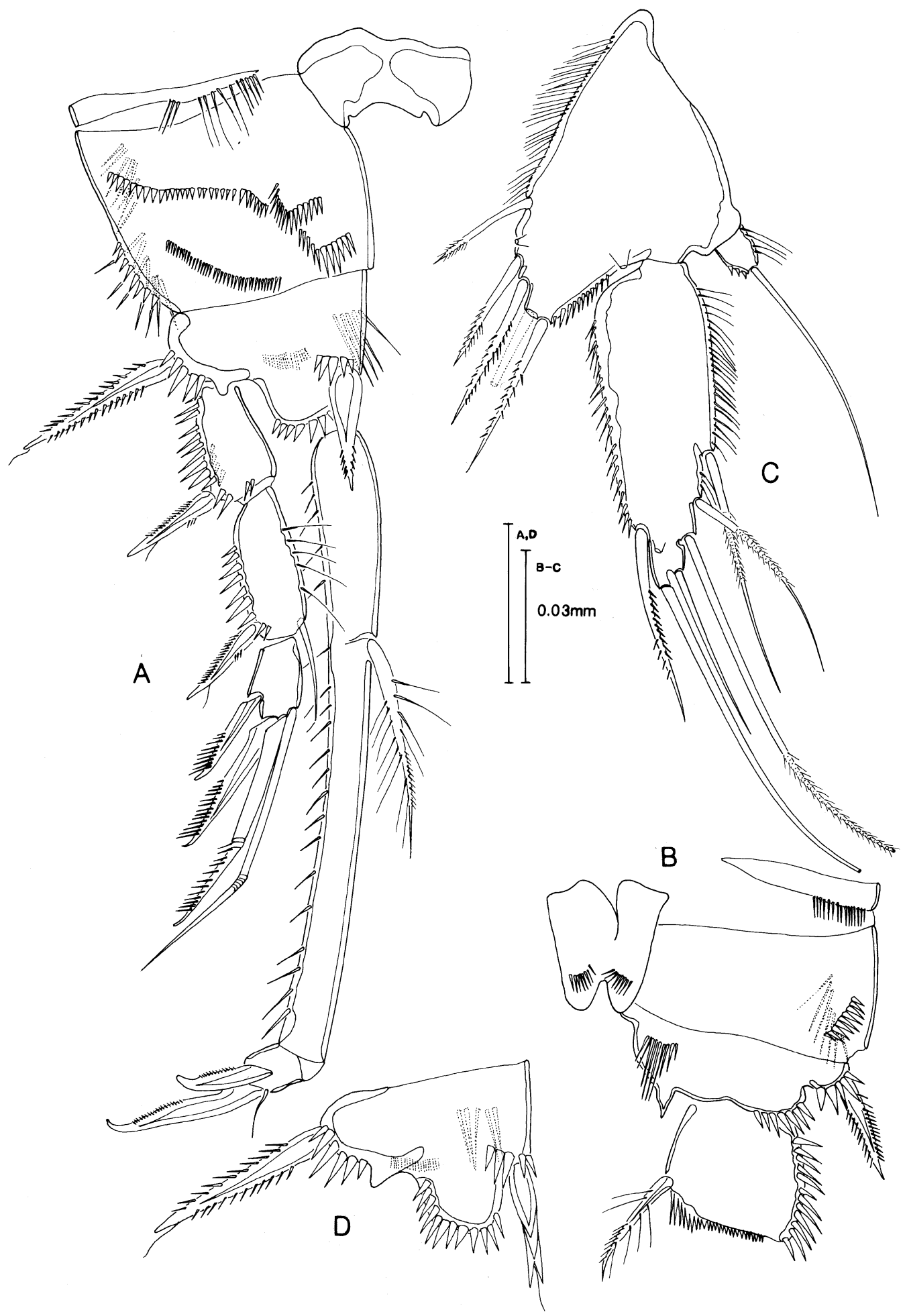

Figure 10. Foweya anglica comb. nov. @: (A) P1; (B) P2 protopod and endopod 1; (C) P5. 3: (D) P1 basis. 


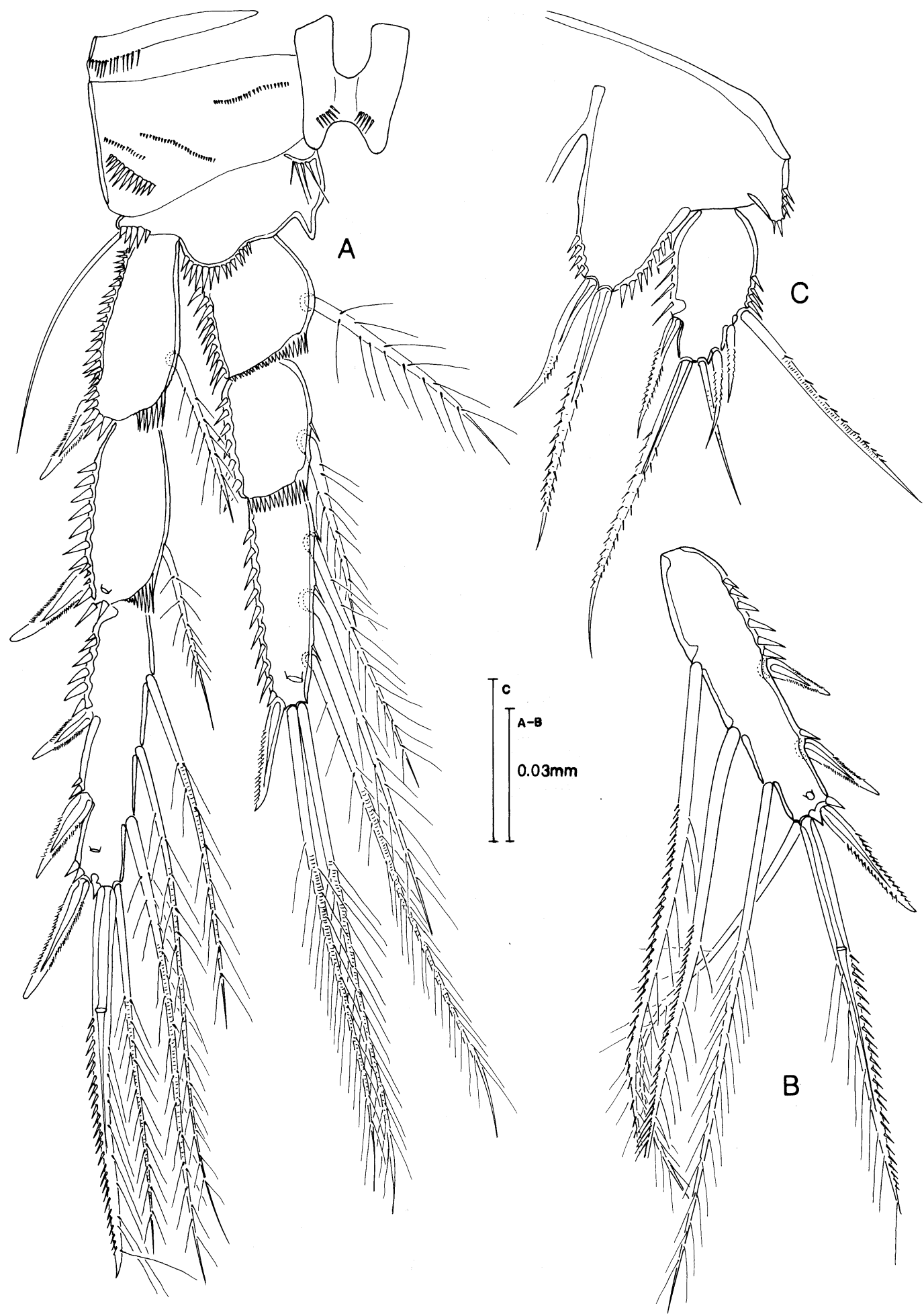

Figure 11. Foweya anglica comb. nov. o:: (A) P3; (B) P4 exopod 3. ô: (C) P5. 
and $1 \hat{\sigma}$ (each dissected onto three slides), NHM Reg. Nos 2006.1984-1985 and 3今 (spirit preserved), NHM Reg. Nos 2006.2003-2005.

\section{Description of female}

Body (Figure 7). Length $0.53 \mathrm{~mm}$, semi-cylindrical, widest at posterior margin of cephalothorax, tapering posteriorly, without clear distinction between prosome and urosome. Cephalothorax tapering anteriorly and with pores and sensilla as in Figure 7A. This and free prosomites with plain hyaline frills. Urosomite-1 (P5-bearing somite) with two short rows of small spinules dorsally. Genital double somite with fusion line marked by lateral sub-cuticular rib and a row of spinules dorsally; posterior margin of double somite with lateral row of short spinules and a ventro-lateral row of longer spinules. Genital apparatus (Figure 7C) consisting of median ventral copulatory pore and separate anterior gonopores armed internally with a row of teeth each covered by a vestigial P6 bearing three setae. Urosomite 4 with lateral row of small spinules and ventral row of larger spinules. Urosomite 5 unadorned. Hyaline frills on urosomites delicate but deeply divided and with minutely dentate distal margin. Anal somite with a row of spinules near ventral anterior margin; partially divided on posterior margin which bears a row of spinules ventrally at base of caudal rami. Anal operculum semi-circular, ornamented with approximately 30 small, closely set denticles (Figures 7B, 8E). Caudal rami (Figure 8E, F) about as long as broad with a diagonal rows of spinules on dorsal face and a row of spinules and a tube pore on ventral posterior margin: bearing seven setae, antero-lateral seta I minute; setae II and III broad, spinulose with terminal flagellum; setae IV and V well developed, seta VI long and naked; triarticulate seta VII arising from dorsal distal part of ramus.

Rostrum (Figure 9A). Well developed, reaching almost to end of segment 2 of antennule, defined at base, triangular with rounded tip and a pair of sub-apical sensilla.

Antennule (Figure 9A). Distinctly nine-segmented, combined length of distal five segments markedly longer than segment 4. All segments without pinnate setae; aesthetascs on segments 4 and 9. Setal formula as follows: 1-[1], 2-[8], 3-[4], 4-[2+(1+a)], 5-[2], 6-[2], 7[2], 8-[2], 9-[5+(2+a)] but some setae probably missing on segments 2 and 3.

Antenna (Figure 9B). Allobasis partially divided, with a pinnate seta and a row of spinules on abexopodal margin. Exopod two-segmented, proximal segment with two setae (a naked proximal seta and a strong pinnate distal seta); distal segment with a distal dentate frill and five setae (two strong pinnate setae on lateral margin and, on distal margin, a strong pinnate seta, a well-developed naked seta and a very small naked seta). Endopod with row of spinules and two sub-distal spines on outer margin; distal margin with two rows of spinules and seven elements, a pinnate spine, four geniculate setae (inner with large pinnules at geniculation) and two plain setae, one of which is fused to base of inner geniculate seta.

Mandible (Figure 9C). Coxal gnathobase well developed with bicuspid and unicuspid teeth and a seta at distal corner. Basis with row of spinules on outer and inner margin and three pinnate setae on distal margin; endopod elongate, one-segmented, with two lateral and six terminal setae; exopod small, one-segmented, with two lateral and two terminal setae. 
Maxillule (Figure 9D). Praecoxal arthrite with six slender elements on distal margin (of which at least one is pinnate at tip), two geniculate surface setae and three pinnate setae on inner margin. Coxal endite with two subdistal setae and four setae on distal margin; coxal epipodite represented by one seta. Basis with seven setae (four on distal margin and three subdistally); rami fused to basis but clearly discerned, endopod one-segmented, flexible and poorly chitinized with four setae; exopod one-segmented with two setae.

Maxilla (Figure 9E). Coxa with row of spinules on outer margin and three endites on inner margin, proximal endite broad and bicuspid with two pinnate setae on inner cusp and two naked setae on outer cusp; middle and outer endite each with three setae (one broad and pinnate); allobasal endite with one fused spine, one articulating, pinnate, spine and two naked setae; endopod with four setae.

Maxilliped (Figure 9F). Syncoxa with two rows of short, and two rows of long, surface spinules and three pinnate setae on distal margin. Basis with row of spinules on outer margin and, on lateral face, bearing two pinnate setae (one much larger than the other) near palmar margin. Endopod represented by a well-developed claw with small teeth on distal inner margin and two accessory setae proximally.

P1 (Figure 10A). Intercoxal sclerite small, oval, unadorned. Praecoxa small, triangular with row of long spinules on distal margin. Coxa with a row of setules on outer margin, a row of spinules at the outer distal corner and four rows of small spinules on anterior face. Basis with rows of spinules on median distal margin and at base of inner and outer stout pinnate spines. Exopod three-segmented, middle segment only slightly longer than proximal segment, distal segment small; proximal and middle segments with row of spinules on outer margin and a spine at outer distal corner; middle segment with a small, naked seta at inner distal corner; distal segment bearing a slender, naked, geniculate seta, a spinulous, geniculate, spine and two spinulose, non-geniculate spines. Endopod two-segmented. Proximal segment elongate, about twice as long as exopod, with a row of spinules on outer margin; at one third of segment length the chitinous segment wall is noticeably thinner and at same point arises a stout, plumose, inner seta; distal segment small, bearing a very small naked seta and two minutely spinulose spines, one twice as long as the other.

P2-P4 (Figures 10B, 11A, B). Intercoxal sclerite with two rows of spinules (except on P4); praecoxa small with row of spinules on distal margin; coxa with row of spinules on outer margin and three rows of spinules on anterior face; basis with row of setules near inner margin and spinules on median distal margin and at base of outer element which is a stout pinnate spine on P2 and a naked seta on P3 and P4. Both rami three-segmented, all segments with row of spinules on outer margin; exp 2 and 3 and enp 3 with pore on anterior face; exp 1 with an inner seta; all setae as shown in figure 11A except inner seta on P2 enp 1 shorter than on other limbs (Figure 10B) and middle inner seta on P4 exp 3 more strongly developed with a serrate margin (Figure 11B). Setal formula of swimming legs as follows:

$\begin{array}{lll} & \text { Exopod } & \text { Endopod } \\ \text { P1 } & 0.1 .022 & 1.111 \\ \text { P2 } & 1.1 .223 & 1.1 .221 \\ \text { P3 } & 1.1 .323 & 1.1 .321 \\ \text { P4 } & 1.1 .323 & 1.1 .221\end{array}$


P5 (Figure 10C). Benps of each side not fused medially and exopods also separate. Benp with well-developed inner expansion triangular in shape with row of setules on inner margin, row of spinules on outer margin and bearing five pinnate setae (four more or less equal in length, inner distal seta, missing in Figure 10C, somewhat longer). Outer basal peduncle of benp with a few spinules and a naked seta. Exopod slender, almost three times longer than wide, with row of pinnules on outer margin and spinules on inner margin, and bearing six setae (one pinnate seta on inner margin, two naked setae on distal margin and three minutely pinnate setae on outer margin).

\section{Description of male}

As in female except for urosome, antennule, P1 basis, P5 and P6.

Body. Slightly smaller than female, length $0.32-0.443 \mathrm{~mm}$ (mean $0.37 \mathrm{~mm}, n=4$ ) and urosomites 2 and 3 not fused (Figure $8 \mathrm{~A}-\mathrm{C}$ ). Body ornamentation as in female except that row of spinules on urosomite 3 complete both dorsally and ventrally.

Antennule (Figure 8D). Ten-segmented, haplocer, with moderately swollen segments 5-7 and major articulation between segments 7 and 8; with row of spinules and aesthetasc on segment 5, acrothek of two setae and small aesthetasc on distal segment. All setae naked. Tentative setal formula:- 1 [1], 2 [10], 3 [8?], 4 [2], 5-7 [11+(1+a)], 8 [2sp+1], 9[4], 10 $[5+(2+a)]$.

P1 basis (Figure 10D). As in female except that inner spine modified to have a bifid tip bearing a minute setule.

P5 (figure 11C). Benps of each side fused medially, inner expansions more rounded than in female, with row of spinules on inner and outer margin and bearing two pinnate setae, outer twice as long as inner. Exopod a single segment, oval, not quite twice as long as wide, with short row of spinules on inner and outer margin and bearing six setae as shown in Figure 11C.

P6 (Figure 8C). A single plate with three setae on a small extension on each side.

Foweya tertia (Kunz) comb. nov.

(Figures 12, 13)

Synonyms

Parastenhelia anglica in Kunz (1963), Karllangia tertia Kunz, 1975.

\section{Material examined}

From paratypes held in Zoologisches Museum Hamburg Reg. No. K 30368 (collected from shell gravel in tidal pools on a reef off East London, South Africa, Kunz, 1975), 1 \% and $1 \hat{\sigma}$ (each dissected onto three slides) NMH Reg Nos 2006.1986-1987 and 1o spirit preserved, NHM Reg. No. 2006.1988. 

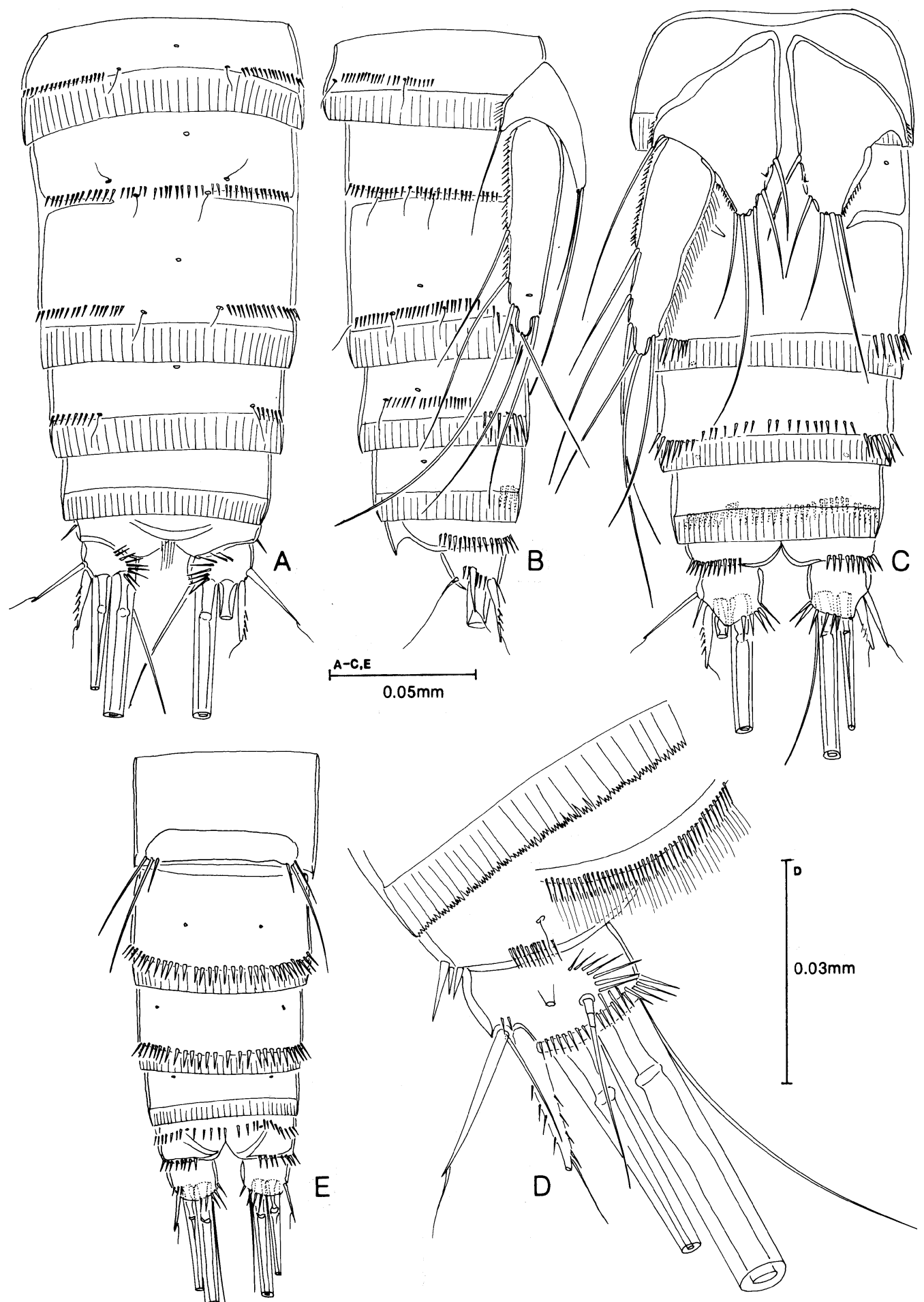

Figure 12. Foweya tertia comb. nov. Q urosome: (A) dorsal view; (B) lateral view; (C) ventral view; (D) operculum and caudal ramus, dorsal view. $\widehat{\jmath}$ : (E) urosome, excluding P5 bearing somite, ventral view. 


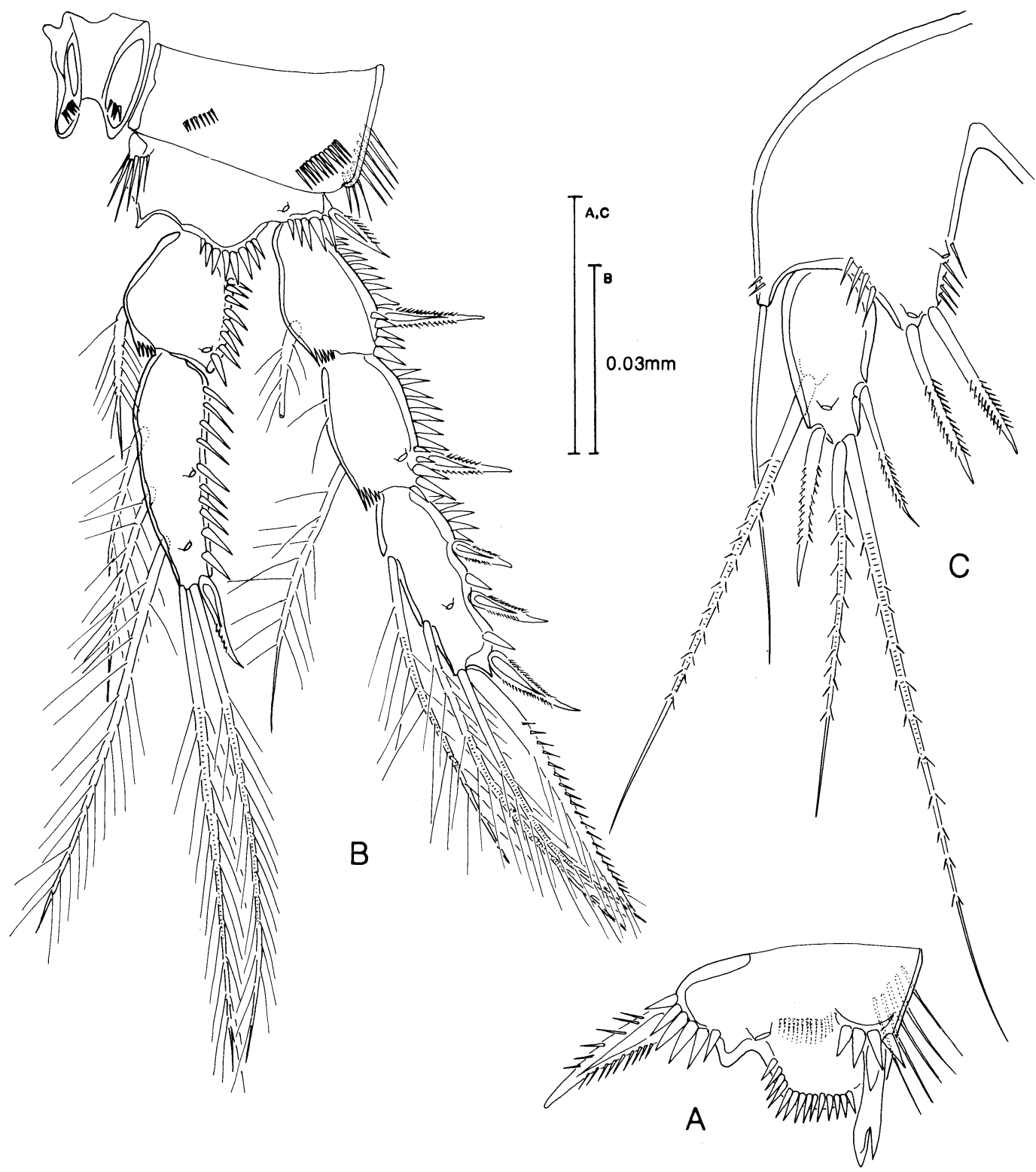

Figure 13. Foweya tertia comb. nov. ơ: (A) P1 basis; (B) P2; (C) P5.

\section{Description of female}

As described by Kunz (1975) with following additions or corrections. Body length of two specimens measured $0.39 \mathrm{~mm}$. Operculum (Figure 12D) semi-circular, ornamented with numerous very fine spinules, only visible under x100 oil immersion. Otherwise body (Figure 12A-C), mouthparts, swimming legs and P5 as for F. anglica. Note that this implies that there is some deviation from the original description in the setation of some of the mouthparts and of the P3 enp 3 given in Table 5 in Kunz (1975). 


\section{Description of male}

Slightly smaller than female. As for male of F. anglica in body ornamentation (Figure 12E) and sexually dimorphic inner spine on P1 basis (Figure 13A). Differs from K. anglica in that $\mathrm{P} 2$ endopod (Figure 13B) is only two-segmented but still carries the same number of setae; the P5 exopod (Figure 13C) bears only five setae (the median inner short seta in F. anglica is missing) and the two setae on the baseoendopod are equal in length.

Genus Parastenhelia Thompson and A. Scott, 1903

Parastenhelia bulbosa sp. nov.

(Figures 14-19)

\section{Synonyms}

Parastenhelia spinosa in Bozic (1955). Parastenhelia spinosa forma bulbosa in Wells (1963). Parastenhelia spinosa in Wells (1970) from Porth Hellick.

\section{Material examined}

Holotype; 1 ( (dissected onto four slides) from St. Martins Flat, Isles of Scilly, NHM Reg. No. 2006.1989. Paratypes, from the same locality as the holotype, 10 (dissected onto three slides) and $2 \hat{\sigma}$ (each dissected onto three or four slides) NHM Reg Nos 2006.1990-1992; 4 o, $4 \hat{\circ}$ and 3 copepodites (spirit preserved), NHM Reg. No. 2006.1993-2002. Other material, $1 \hat{\sigma}$ (spirit preserved) collected by University of London Sub-Aqua Club in gravel at low water at Porth Hellick, St Marys, Isles of Scilly, NHM Reg. No. 1967.10.31.50.

\section{Description of female}

Body. Length (of contracted specimens) $0.41-0.49 \mathrm{~mm}$ (mean $=0.46 \mathrm{~mm}, n=4$ ), semicylindrical, widest at posterior margin of cephalothorax, tapering posteriorly without clear distinction between prosome and urosome. Urosomites (Figure 14A-C) with wide, palisade hyaline frills finely dentate on posterior margin (Figure 15A). Genital doublesomite (Figure 14A-C) completely fused without trace of sub-cuticular rib, ornamented only with a short ventro-lateral row of spinules on posterior margin. Genital apparatus (Figure 14C) with median ventral copulatory pore and separate anterior gonopores, each armed internally with a row of teeth and covered by a vestigial P6 bearing three setae. Urosomites 4 and 5 with short lateral row of spinules on posterior margin. Anal somite with median ventral row of short spinules and, on posterior margin, a ventral and lateral row of stronger spinules and setules on dorsal margin; anal operculum (Figure 15A) semi-circular with a sub-marginal row of minute spinules and a marginal row of about 35 larger spinules. Caudal rami (Figure 15A, B) broader than long, with rows of spinules on inner and outer margin, diagonally across dorsal surface and around ventral posterior margin; minute seta I and larger seta II implanted anteriorly on lateral margin; robust seta III implanted at distal outer corner; terminal seta IV moderately slender but with characteristic swollen bulbose base; terminal seta $\mathrm{V}$ robust, large without noticeably swollen base; terminal, inner seta VI small and slender and triarticulated seta VII implanted on dorsal surface. 


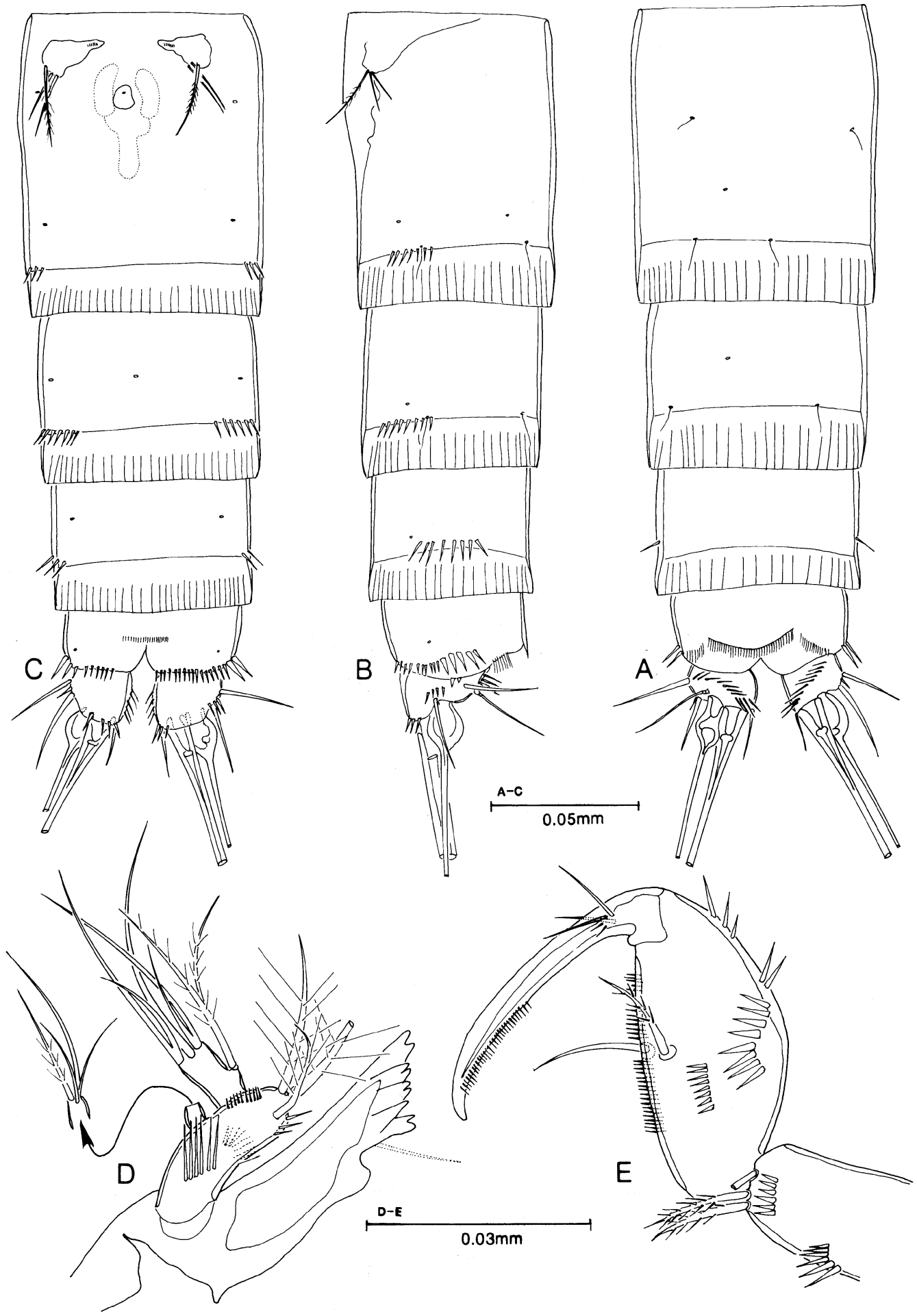

Figure 14. Parastenhelia bulbosa sp. nov. Q: urosome, excluding P5 bearing somite (A) dorsal view; (B) lateral view; (C) ventral view: (D) mandible; (E) maxilliped. 


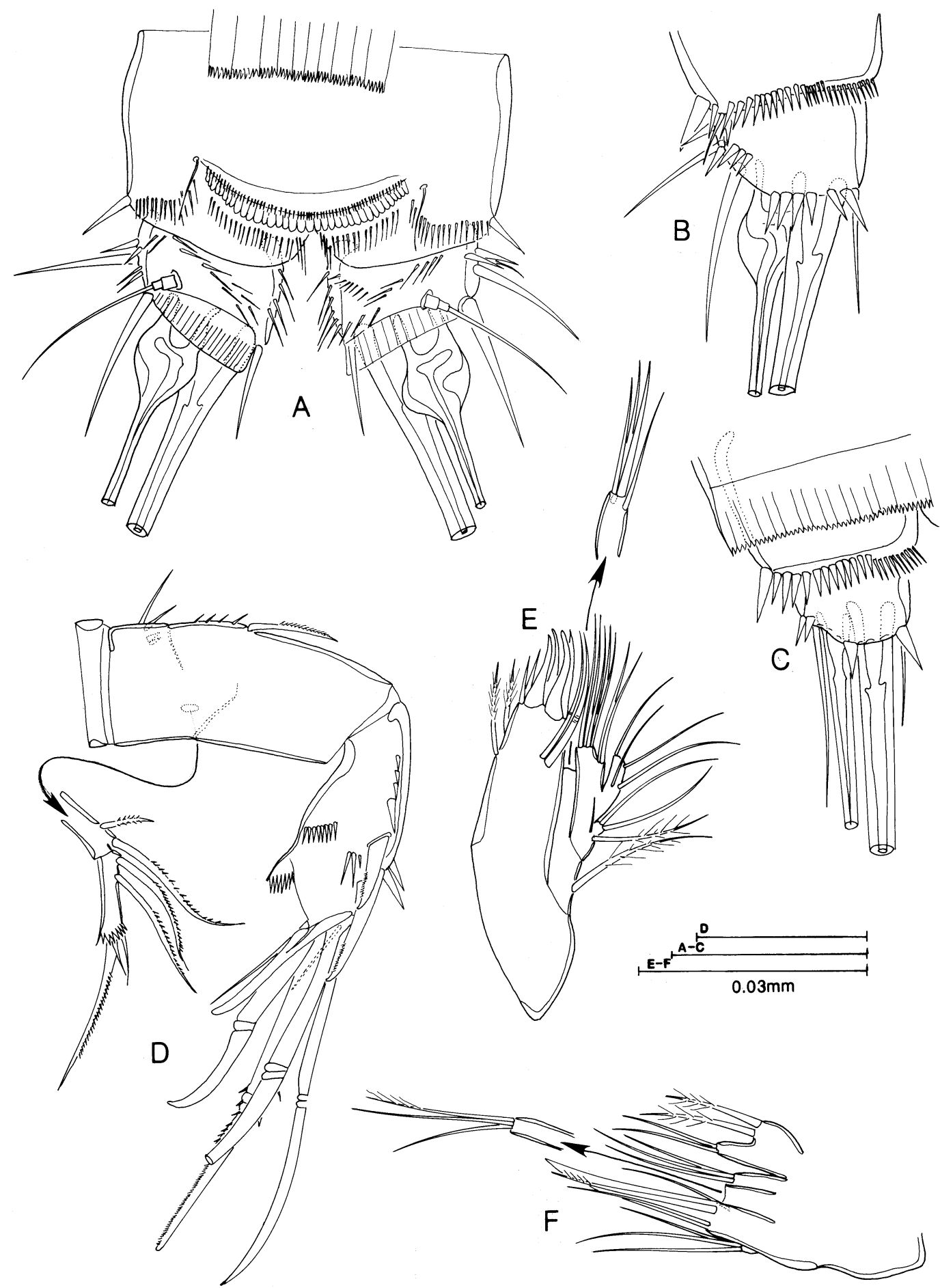

Figure 15. Parastenhelia bulbosa sp. nov. ọ: (A) anal somite and caudal ramus, dorsal view; (B) caudal ramus, ventral view; (D) antenna. ơ: (C) caudal ramus, ventral view; (E) maxillule; (F) maxilla. 

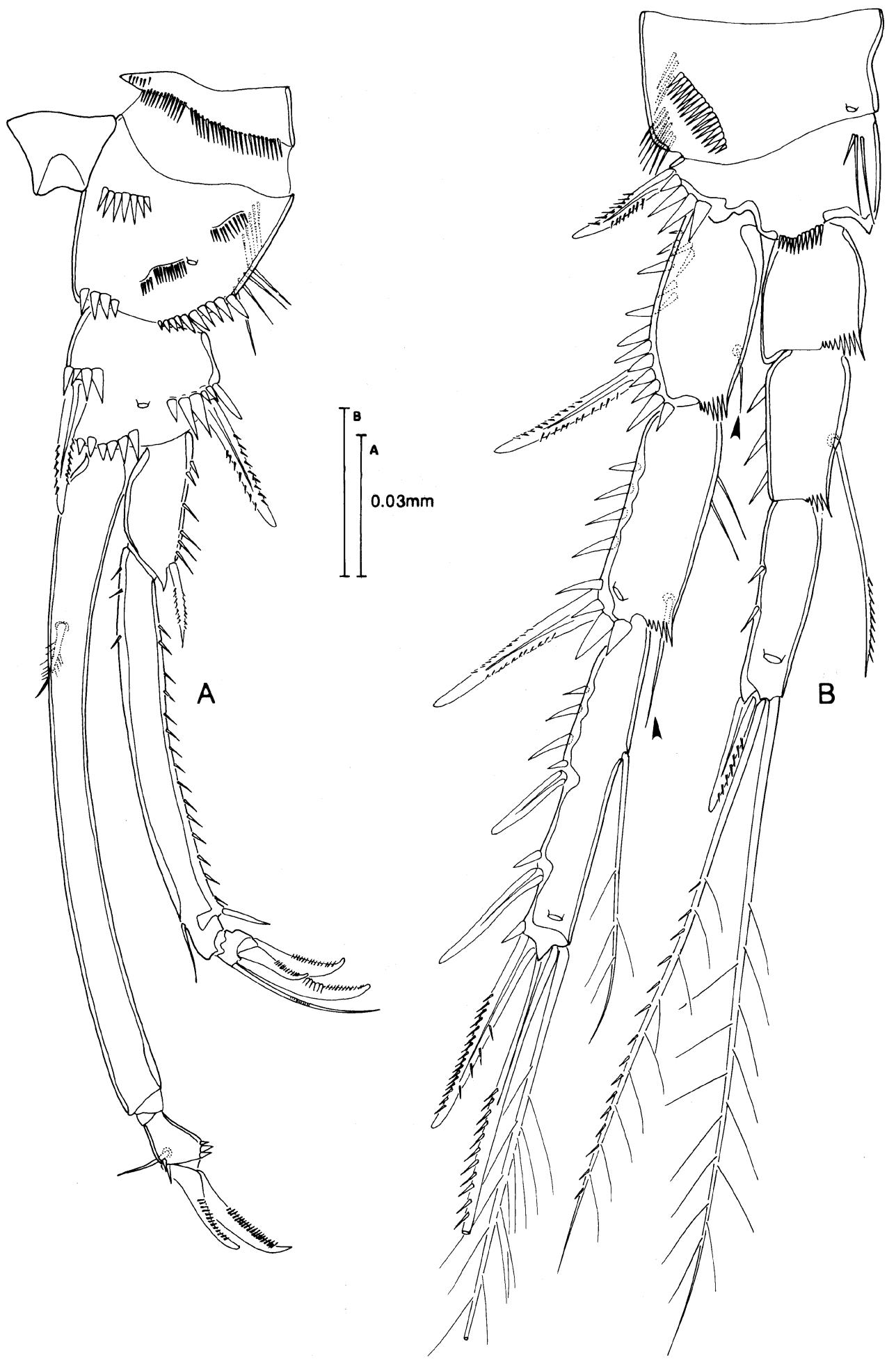

Figure 16. Parastenhelia bulbosa sp. nov. o: (A) P1; (B) P2. 

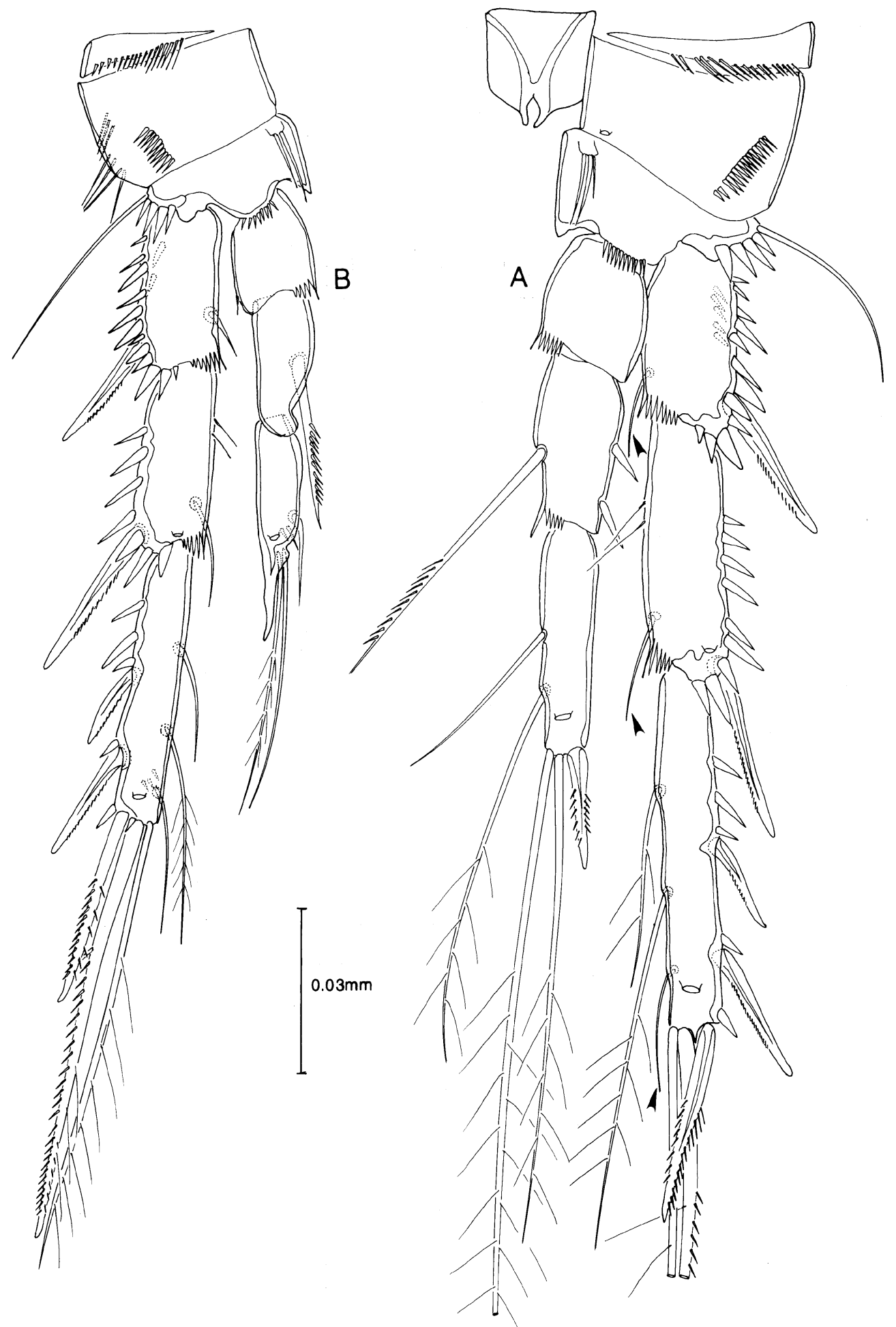

Figure 17. Parastenhelia bulbosa sp. nov. P3: (A) ९; (B) $\oint^{t}$. 


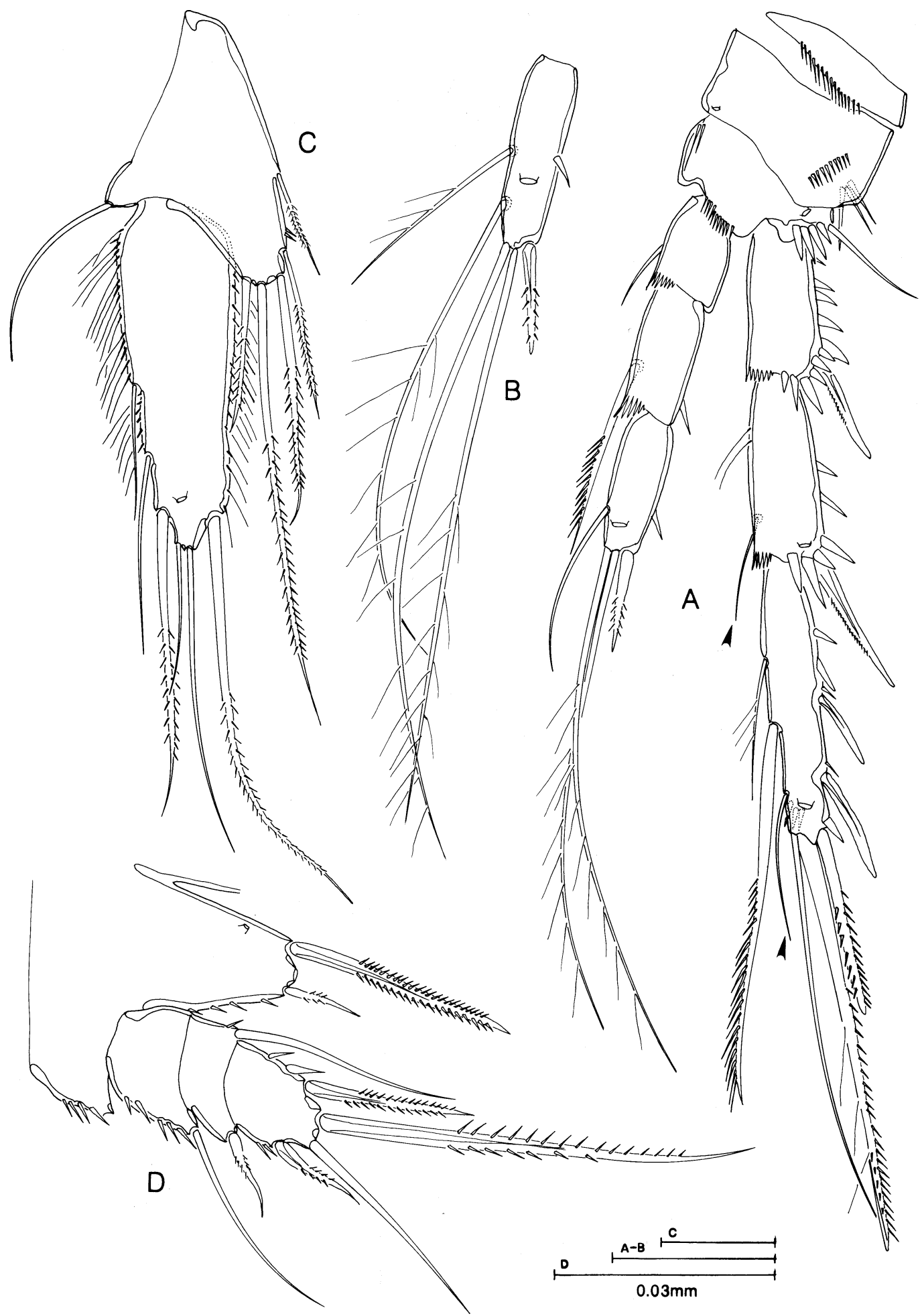

Figure 18. Parastenhelia bulbosa sp. nov. P4: (A) ô; (B) ९ endopod 3. P5: (C) $९$ (D) $\widehat{0}$. 

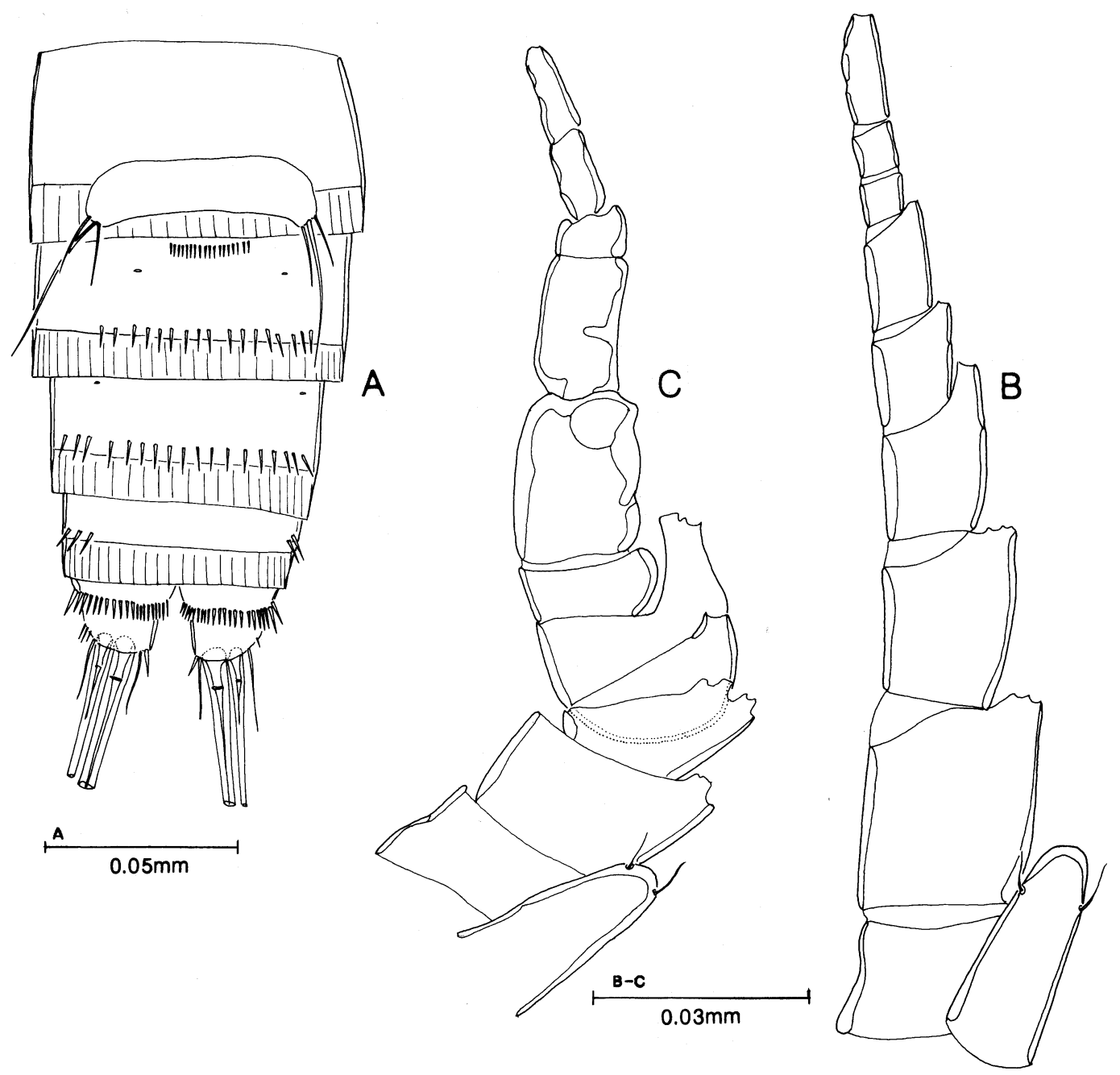

Figure 19. Parastenhelia bulbosa sp. nov. ơ: (A) urosome, excluding P5 bearing somite, ventral view, (C) rostrum and antennule segmentation. ọ: (B) rostrum and antennule segmentation.

Rostrum (Figure 19B). Moderately small, only reaching a short way past proximal margin of second antennular segment, defined at base, triangular with rounded tip and a pair of subapical sensilla.

Antennule (Figure 19B). Distinctly nine-segmented, combined length of distal five segments markedly longer than segment 4; all segments without pinnate setae, aesthetascs on segments 4 and 9. Tentative setal formula as follows 1-[1], 2-[10], 3-[8], $4-[2+(1+a)], 5-[2], 6-[4$ ?], 7-[2?], 8-[2?], 9-[5+(2+a)].

Antenna (Figure 15D). Allobasis partially divided, abexopodal margin with a proximal transverse row of spinules and a more distal vertical row of spinules below a pinnate seta. Exopod two-segmented, proximal segment with two setae, distal segment with five setae (two proximal, lateral setae and one large and two small setae on distal margin) and a 
subdistal row of spinules. Endopod with row of spinules and two minutely pinnate subdistal spines on outer margin; distal margin with two rows of spinules and seven elements, a pinnate spine, four geniculate setae (inner with large pinnules at geniculation) and two plain setae, one of which is fused to base of inner geniculate seta.

Mandible (Figure 14D). Coxal gnathobase well developed with bicuspid and unicuspid teeth and a seta at distal corner. Basis with rows of spinules on outer and inner margin and across anterior and posterior face and with three pinnate setae on distal margin; endopod elongate, one-segmented, with two lateral and five terminal setae (two pairs fused at base); exopod small, one-segmented, with four setae.

Maxillule (Figure 15E). Praecoxal arthrite with six slender elements on distal margin, two geniculate surface setae and two pinnate setae on inner margin. Coxal endite with four setae on distal margin; coxal epipodite represented by one seta. Basis with seven setae (five on distal margin and two subdistally); rami fused to basis but clearly discerned, endopod one-segmented, with four setae; exopod one-segmented with four setae.

Maxilla (Figure 15F). Coxa with three endites on inner margin, proximal endite broad and bicuspid with two pinnate setae on inner cusp and two naked setae on outer cusp; middle and outer endite each with three setae; allobasal endite with one fused spine, one articulating, pinnate, spine and two naked setae; endopod with four setae.

Maxilliped (Figure 14E). Syncoxa with two rows of short surface spinules and three pinnate setae on distal margin. Basis with row of spinules on outer margin, on lateral face and on palmar margin, which also bears two setae. Endopod represented by a well-developed claw with small teeth on distal inner margin and three accessory setae proximally.

P1 (Figure 16A). Intercoxal sclerite small, unadorned. Praecoxa, small, triangular with row of spinules on distal margin. Coxa almost square with row of setules on outer margin, rows of strong spinules on inner and outer distal margin and three rows of spinules on anterior face. Basis also almost square, with row of strong spinules at base of inner and outer pinnate spine and on distal margin at base of endopod. Exopod three-segmented, proximal segment with row of spinules on outer margin and a spine at outer distal corner; middle segment markedly elongate, three times longer than proximal segment, with row of spinules on outer margin, a small spine at outer distal corner and a small seta at inner distal corner; distal segment very small, bearing a short, slender geniculate seta and one geniculate and two non-geniculate, recurved, short, strong spines. Endopod two-segmented, proximal segment longer than entire exopod with a small, pinnate seta implanted within proximal third of segment; distal segment small with a few spinules, one minute seta and two short, recurved, dentate spines.

P2-P4 (Figures 16B, 17A, 18B). Intercoxal sclerites unadorned; praecoxa small triangular with spinule row on distal margin; coxa broader than long with row of setules on outer margin and row of spinules on anterior face; basis with row of setules near proximal inner margin, row of fine spinules distally at base of exopod and row of strong spinules near base of endopod, with pinnate outer spine on P2 and slender naked outer seta on P3 and P4. Rami three-segmented, segments with variable row of spinules on outer margin, exp 2 and 3 and enp 3 with pore on anterior face; exp 1 with inner seta on P2 and P3. The inner seta 
on exp 1 and exp 2 and the distal inner seta on exp 3 are extremely small or slender, are inserted on the posterior face and often lie along the posterior face of the succeeding segment. They are therefore, sometimes very difficult to see even with x100 oil immersion objective. The setal formula is as follows:

\begin{tabular}{llll} 
& Exopod & \multicolumn{2}{c}{ Endopod } \\
P1 & 0.1 .022 & 1.111 & \\
P2 & 1.1 .123 & 0.1 .021 & \\
P3 & 1.1 .323 & 0.1 .221 ○ิ $0.1 .12+$ apophysis \\
P4 & 0.1 .323 & 1.1 .221 ○ิ 1.1 .121
\end{tabular}

P5 (Figure 18C). Benps of each side not fused medially and exopods also separate. Benp with well-developed inner expansion triangular in shape with row of setules on inner margin and bearing five pinnate setae, lengths as shown in Figure 18C. Outer basal peduncle of benp with a naked seta. Exopod slender, three times longer than wide, with row of pinnules on outer margin and spinules on inner margin, and bearing six setae (one pinnate seta on inner margin, two naked setae on distal margin and one pinnate and two naked setae on outer margin).

\section{Description of male}

As in female except for urosome, caudal ramus, antennule, P3, P4, P5 and P6.

Body. Slightly smaller than female, contracted length $0.34-0.36 \mathrm{~mm}$ (mean $=0.35 \mathrm{~mm}$, $n=5$ ) and urosomites 2 and 3 not fused. Body ornamentation (Figure 19A) as in female except urosomite 3 with row of small spinules near ventral anterior margin and urosomites 3 and 4 with complete row of spinules on ventral posterior margin. Caudal ramus seta IV not swollen at base (Figure 19A).

Antennule (Figure 19C). Eleven-segmented, haplocer with moderately swollen segments 57 , with major articulation between segments 7 and 8 and with four segments distal to articulation; aesthetascs on segments 5 and 11 and all setae naked; tentative setal formula as follows: 1-[1], 2-[10], 3-[8], 4-[4?], 5-[2+(1+a)], 6-[4?], 7-[2], 8[2 modified spines], $9,[1], 10-[4], 11-[5+(2+a)]$.

P3 (Figure 17B). Exopod as in female. Enp 2 more slender than female with a shorter, stouter inner seta; enp 3 shorter than female, with one small seta on inner margin, two setae on distal margin and the outer spine fused to the segment to form an apophysis at outer distal corner.

P4 (Figure 18A). As in female except that enp 3 has only one inner naked seta.

P5 (Figure 18D). Benps of each side fused medially, inner expansions more rounded than in female, with row of spinules on outer margin and bearing two pinnate setae separated by a pore, inner twice as long as outer; outer peduncle bearing long naked seta (lost in Figure 18D). Exopod three-segmented, oval, overall not quite twice as long as wide; proximal segment with row of spinules on outer margin and a naked seta at outer distal corner; middle segment with long naked seta on inner margin and short pinnate seta at 
outer distal corner; distal segment with spinule row on inner and outer margin, and with three pinnate and one naked seta.

P6 (Figure 19A). A single plate with three setae on each side.

\section{Variability}

In one dissected male the P2 enp 2 lacked the inner terminal seta on one side and the outer seta on the benp of the P5 on one side was implanted close to the inner seta and was twice as long as shown in Figure 18D. In one dissected female the P3 exp 1 lacked the inner seta on both sides.

\section{Discussion}

\section{Karllangia}

Monard (1935) described Thalestrella ornatissima from a single female (0.4 mm long) found in sublittoral sand near Roc'h Iliévec in the region of Roscoff. He was unable to place it with any certainty in a family because he thought it was like the Diosaccidae in the rostrum, the Thalestridae in the antenna, mouthparts and P1, and the Ameiridae in general appearance, the P2-P4 and the operculum. Subsequently, Lang (1948) transferred Thalestrella to the genus Parastenhelia. Since Monard's (1935) description, there have been only three references to this species being found elsewhere, firstly by Por (1964) who found seven females in eulittoral detrital sand at Achzib, north of Haifa on the Mediterranean coast of Israel, "which agreed with Monard's description in all respects except that the operculum had only seven large teeth and the baseoendopodal setae of the P5 were a little shorter'. Secondly, Bodin (1968) reported finding seven females and nine males in a midlittoral sand sample from Banc du Bûcheron (Ile de Ré) near La Rochelle, but gave no morphological details of any of the specimens. Finally, Thistle (1980) found two specimens of a Parastenhelia c.f. ornatissima in sublittoral fine sand off seagrass beds in St. George's Sound, Florida.

Unfortunately there is no type material of $P$. ornatissima but the description and figures in Monard (1935) are reasonably good. In Monard's single specimen and the present material from the Scilly Isles, the general body facies of prominent hyaline frills, body ornamentation and coarsely toothed operculum agree, although in his Figure 89 Monard shows the operculum with about 12 teeth. The proportions of the segments of the female antennule are the same although Monard does not show (Figure 90) a partial suture on the distal segment. Monard twice illustrates, in Figure 91, a two-segmented antennal exopod but the number of setae on the proximal segment and the arrangement of the four setae on the distal segment are different in each drawing. The Scilly Isles material has only three setae on the distal segment of the A2. Monard also illustrates the maxilliped (Figure 92) and shows only one seta on the syncoxa (as in my material) but a large seta on the inner margin of the basis (instead of two small ones). The proportions and setation of the P1 agree, as do the segmentation and general setation of the P2-P4. However, whilst there is no seta on P2-P4 exp-1, Monard shows (Figures 94-96) only a small weak seta on P2-P4 exp 2 (instead of a normally developed one as in Figure 5B) and only two inner setae on P4 exp 3 (the seta distal to the large medial seta in Figure $5 B$ is the one missing). In his Figure 86, Monard illustrates the female P5 exopod as only about three times longer than wide (but states it is four times longer than wide in the text) rather than the five times in my material. Finally, Monard illustrates and describes (Figure 88) the caudal ramus with a 
transverse row of setules on the ventral face. This latter point is clearly incorrect as all Parastenheliidae have this transverse setule row on the dorsal surface of the caudal ramus. Monard's imprecision with respect to the setation of the exopod of the antenna suggests that he did not pay too much attention to the setation of the mouthparts so, in my opinion, no great significance should be attached to these differences. The setation of P4 exopod 3 is probably the only significant difference between Monard's specimen and the Scilly Isles material, especially as Por (1964) indicated that he found specimens with the same setation of the swimming legs. However, it is perfectly possible that Monard's specimen had accidentally lost this seta, either in dissection or in capture and as the Scilly Isles are only a short way from Roscoff compared to Por's site on the eastern shore of the Mediterranean, I feel justified in synonymizing my material with Parastenhelia ornatissima and suggesting that Por's material could be a different species.

With the discovery of the male of $P$. ornatissima it was clear that this species has characteristics not found in other species of Parastenhelia but which are diagnostic of the genus Karllangia. Noodt (1964) placed his genus in the Ameiridae but both Mielke (1994) and Huys et al (1996) suggested that it should probably belong in the Parastenheliidae. This was confirmed by the phylogenetic analysis of Willen (2000) who formally placed Karllangia in the Parastenheliidae. The principal apomorphy which distinguishes Karllangia from other members of this family is the sexual dimorphism of the antenna (allobasal seta much more plumose in the male and the exopod proximal segment smaller and with only one strong, plumose seta and distal segment broader with more strongly plumose setae than in the female). Sexual dimorphism of the antenna is rare within the Harpacticoida but has arisen independently a number of times. Apart from Karllangia, the most pronounced modifications in segmentation and/or setation of the antenna between the sexes are to be found in Aegisthus Giesbrecht, 1891 (Aegisthidae), Tigriopus Norman, 1868 (Harpacticidae) and Diarthrodella Klie, 1949 (Paramesochridae) but slight modifications in segmentation or spinular ornamentation are to be found in a number of other genera or families (see review in Huys 1988). Other apomorphies for the genus Karllangia include the compressed appearance of the distal segments of the female antennule; the presence of only three setae on exp 2 of the antenna, a mandibular exopod with only two setae; a maxillipedal syncoxa with only one seta, P2-P4 exp 1 without an inner seta and a male P5 exopod with only four setae.

The other species at present in the genus Karllangia are the type species, $K$. arenicola and $K$. tertia, K. psammophila, K. bengalensis, $K$. pulchra and $K$. obscura. As will be shown below $K$. tertia, described by Kunz (1975) from shell gravel in tidal pools near East London, South Africa, does not belong in Karlangia as it exhibits none of the above mentioned apomorphies for that genus but is very closely related to $P$. anglica. Wells (1967) originally described $K$. psammophila (from Inhaca Island) as a separate species but later Wells and Rao (1987) reduced it to a subspecies of $K$. arenicola along with another form ( $K$. arenicola bengalensis) which they found in the Andaman and Nicobar Islands. This species they stated was identical to $K$. psammophila in all respects except for the lack of an attenuated outer distal border on the first segment of the antennule of both sexes. However, in my opinion there are additional significant differences in the setation of the swimming legs and the ornamentation of the operculum to warrant specific status for both these forms. I have examined paratype specimens of $K$. psammophila (NHM Reg. No, 1967.8.4.62) and found the following corrections to the description in Wells (1967): a seta is present on the abexopodal margin of the allobasis of the antenna; the female antennal exopod has two setae on the proximal segment and one lateral seta and two distal setae on the distal 
segment although the boundary between the segments is indistinct; the mandibular basis bears three setae and a small exopod bearing two setae is present; the maxillipedal syncoxa bears one seta and the basis has two setae on the palmar margin. I have not been able to examine specimens of $K$. bengalensis but assume the same corrections apply to that species. An outstanding problem within this genus is the fact that the original description by Noodt (1964) of the type species $K$. arenicola from coralline sands on the Egyptian coast of the Red Sea does not mention any sexual dimorphism in the male antenna. As far as I am aware $K$. arenicola has not been found again and unfortunately I have been unable to locate Noodt's material, despite extensive enquiries and searches by Dr Ruth Bottger-Schnack. It is quite possible that this feature was overlooked by Noodt because all the species of Karllangia are very small and, as stated above, sexual dimorphism in this limb is a very unusual feature. It was certainly overlooked by Wells (1961) when he identified specimens from St Martins in the Scilly Isles as $P$. anglica which were, in fact, the species under consideration here.

Apostolov (1975) described a new species, Parastenhelia reducta Apostolov, 1975 based on one female and one male from sandy sediments at $5 \mathrm{~m}$ depth on the Bulgarian coast of the Black Sea. He suggested that the reduced limb setation of the P2-P4 of this species (no inner seta on exp 1 and only two inner setae on exp 3) indicated a close relationship with $P$. ornatissima. Indeed, in addition to the reduced setation of P2-P4 there are other features of $P$. reducta which would suggest it might belong to Karllangia; namely the female antennule has markedly compressed terminal segments; the maxillipedal syncoxa bears only one seta, and there is no sexual dimorphism in the swimming legs. However, the male P5 exopod has five setae (instead of the four in Karllangia) and, according to Apostolov (1975), the female antenna is as described by Monard for P. ornatissima (with one seta on the proximal segment and four on the distal segment) and there is no sexual dimorphism in the male antenna. If this latter statement is true, it would definitely exclude $P$. reducta from Karllangia. As stated above however, it is posssible for this character to be overlooked and in Apostolov's Figure $3 \mathrm{~h}$ he has drawn (but not commented upon in the text) a peculiar structure attached to, or underlying, the second segment of the male antennule which has not been seen in any other parastenheliid but which could be part of a modified male antenna. There is, therefore, a need for this species to be re-examined but until that is possible, I suggest that $P$. reducta should be placed incertae sedis in Karllangia.

\section{Key to species of Karllangia}

1. P3 exp 3 with two inner setae . . . . . . . . . . . . . . . . . . . $\quad$. 2

P3 exp 3 with three inner setae . . . . . . . . . . . . . . . . . 3

2. P1 exp 2 without inner seta, operculum with ca 16 teeth . . . . K. arenicola P1 exp 2 with inner seta, operculum with 6-8 teeth . . . . . K. ornatissima

3. $९$ P5 exp with five setae, operculum with approx, 40 setules, no sexual dimorphism

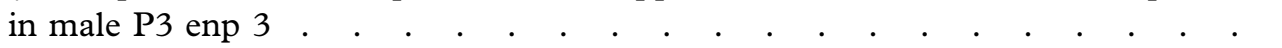
ㅇ P5 exp with six setae, operculum with 12-25 spinules, outer spine in $\widehat{\sigma} \mathrm{P} 3 \mathrm{enp} 3$ very reduced

4. Outer corner of proximal segment of A1 attenuated . . . . . K. psammophila Outer corner of proximal segment of A1 normal . . . . . . K. bengalensis

5. P1 exp 2 with inner seta, hyaline frills lobate . . . . . . . . K. pulchra P1 exp 2 without inner seta, hyaline frills plain . . . . . . . K. obscura 


\section{Foweya}

Parastenhelia anglica was first described by Norman and T. Scott (1905) and first figured in Norman and T. Scott (1906) from one or two female specimens dredged from about three fathoms outside Fowey harbour, Cornwall. They placed it in Parastenhelia because it was almost identical to Parastenhelia hornelli, except that Norman and T. Scott thought that the P1 endopod in their specimen was three-segmented instead of two-segmented. This, however, was a misinterpretation as the chitin of the segment wall is very thin at the point of insertion of the inner seta and in mounted specimens sometimes kinks to give the appearance of a segment boundary. Norman and T. Scott (1906) did not mention the setation of P2 and P3 and the slide of the type specimen in the Natural History Museum is all but dried out and only the P5 is discernible with any degree of clarity.

Parastenhelia anglica was not mentioned again until Wells (1961) reported finding large numbers of both sexes at around mid- to low water on the sand flats of Tresco and St. Martins in the Scilly Isles. He briefly described the antennule and P5 of the male, stating that the latter limb had four setae on the exopod. The last description of $P$. anglica was given by Kunz (1963) based on three females and one male from intertidal sands in Southwest Africa. He described the P1 with a narrowing of the chitin wall of the proximal endopod segment, gave the full setal formula of the swimming legs, described a twosegmented endopod of the male P2 and disagreed with Wells (1961) in that his male specimen had five setae on the P5 exopod.

It is clear, based on the abundance and location data along with the description of the male P5 given in Wells (1961), that the specimens which he identified as P. anglica were, in fact, those that I have described above as $K$. ornatissima. Similarly, the specimens from Southwest Africa that Kunz (1963) described as $P$. anglica are identical to specimens he later described (Kunz 1975) from southeast Africa as K. tertia.

Although the female specimen described here is a little smaller $(0.53 \mathrm{~mm})$ than that in the original description $(0.65 \mathrm{~mm})$ and there are some discrepancies in the mouthparts (which I have noted above were not always reliably described by early authors) I am confident that my specimens can be assigned to the $P$. anglica of Norman and $\mathrm{T}$. Scott (1905, 1906). The Scilly Isles are only a few miles from the type locality of the species; the P1 is the same as shown in Norman and T. Scott (1906) (plate XVI, Figure 4) with an area of narrowing of the chitin wall in the region of the inner seta on endopod 1 ; the ornamentation of the female urosome, including the distinctive row of setules near the anterior ventral border of the anal somite is the same as that illustrated by Norman and $\mathrm{T}$. Scott (1906) (plate XIII, Figure 4) except that the latter authors also show an antero-lateral row of setules on urosomite 4; the female P5 exopod is of the same dimensions and armature as that shown by Norman and T. Scott (1906) (plate XVII, Figure 4). The true characteristics of the male of this species are therefore those described in this paper; most noticeably a 10-segmented antennule with three segments distal to the geniculation; a sexually dimorphic, bifid, inner basal spine on the P1; no sexual dimorphism on any of the other swimming legs and a P5 exopod of one segment with six setae.

As noted above, $K$. tertia does not belong in Karllangia as the male does not have a sexually dimorphic antenna and the P5 has five setae; in the female, the distal segments of the antennule are not compressed; in both sexes the antennal exopod has five setae on the distal segment, the mandibular exopod has four setae, the maxillipedal syncoxa has three setae and the P2-P4 exopod 1 has an inner seta. However, it is clear that K. tertia is very closely related to $P$. anglica. The pre- and post-oral appendages are identical in both species; the structure of the P1 (exopod 2 only slightly longer than exopod 1; endopod 1 
with thin-walled region; male inner basal seta with bifid tip) is the same and the setal formula of the swimming legs is identical and unique within the family. The two species can be distinguished, in both sexes, by the ornamentation of the operculum and, in the male, by the number of setae on the P5 exopod and the segmentation of the P2 endopod (twosegmented in $K$. tertia as a result of the failure of the second and third segments to separate).

These two species have been placed in a new genus Foweya on the basis of the following characters:

(1) The principle apomorphy is the bifid, sexually dimorphic inner spine on the P1 basis which has not been reported in any other species in the family.

(2) The narrowing of the chitin wall on the P1 endopod 1 is a character shared with Karllangia but has not been reported for any other species of Parastenhelia.

(3) The 10-segmented male antennule with only three segments distal to the articulation is probably an apomorphy. It is shown earlier that Karllangia also has three segments distal to the articulation but the segments 5-7 making up the swollen section of the limb in Foweya are fused into a single segment in Karllangia. Unfortunately details of the male antennule in this family have rarely been reported in the literature but as far as I can ascertain in other Parastenhelia species, the antennule is probably 11segmented with four segments distal to the geniculation (see Figure 19B in the present paper and Figure 2F in Song et al. 2003).

(4) The other distinctive characteristics of Foweya are probably the plesiomorphic condition for the family. One of these is the absence of sexual dimorphism in the endopod of P3, another character shared only with Karllangia. The two-segmented condition of the P2 endopod in $F$. tertia (but retaining the female armature complement) is found in four species of Parastenhelia (see Figure 20).

(5) Foweya also has the most primitive setal formula within the family. The two species are the only ones to have two inner setae on the terminal segment of each ramus of the P2 and to have three inner setae on P3 enp 3. Pallares (1982) described Parastenhelia costata Pallares, 1982 with three inner setae on this segment but Mielke (1990) found only one or two setae in this position in specimens he tentatively identified as $P$. costata.

\section{Parastenhelia}

Bozic (1955) described Parastenhelia spinosa from Roscoff in which the female outer terminal seta (seta IV) was distinctly swollen and bulb-shaped while the inner terminal seta (seta V) was more or less normal at the base. Wells (1961) reported finding many similar specimens in the Scilly Isles and Wells (1963) also found them at two sites in the estuary of the River Exe and in the latter publication formally proposed to distinguish them as $P$. spinosa var. bulbosa.

Parastenhelia spinosa was first described as Harpacticus spinosus by Fischer (1860) from the island of Madeira but the description is lacking in any real detail (eight-segmented antennule and P5 with four spines on exopod and baseoendopod) and only the drawing of the P1 could identify it as a Parastenhelia. Lang (1948) gives the full synonymy of the genus and in his review suggests that $P$. forficula, $P$. littoralis and $P$. littoralis $\mathrm{f}$. penicillata should be regarded as three forms (forma typica, forma littoralis and forma penicillata respectively) of a single species, $P$. spinosa. He maintained that "it is impossible to keep the three forms apart because a number of intermediate forms are present and the combination of characters vary 
FEMALE

P2 endopod
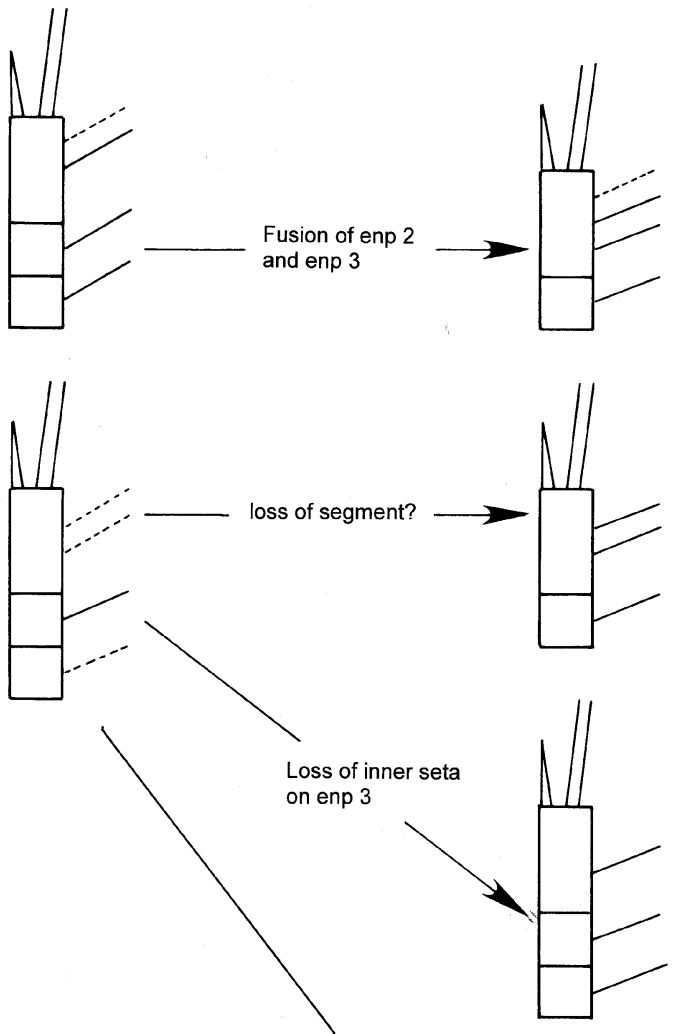

enp 3 outer spine forming apophysis: loss of inner seta(e)

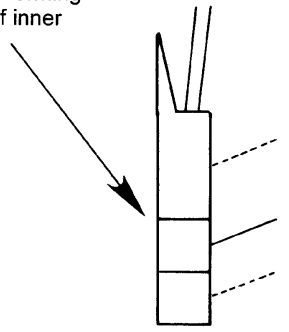

\section{P3 endopod}

\section{P4 endopod}

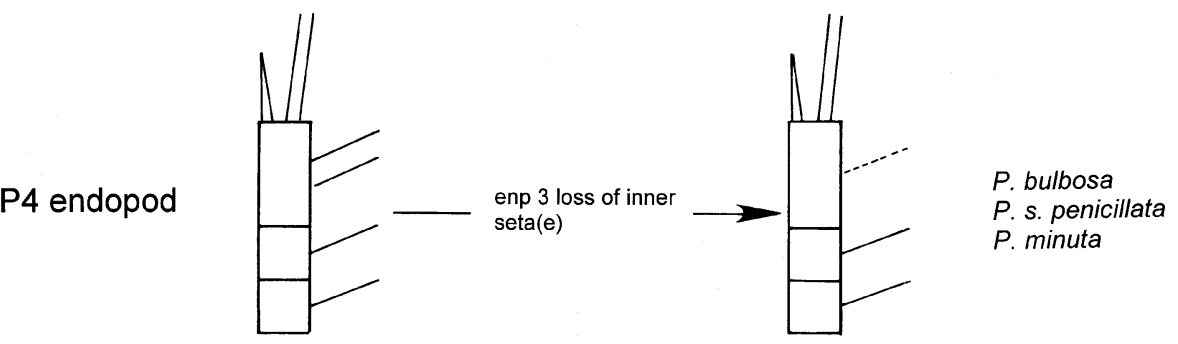

MALE

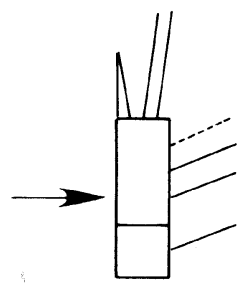

F. tertia

P. pyriformis

P. costata

$P$. oligochaeta

$P$. hornelli

\section{P. pyriformis}

P. megarostrum
P. bulbosa
P. costata
P. minuta
$P$. gracilis
$P$. spinosa
$P$. oligochaeta
$P$. hornelli

Figure 20. Sexual dimorphism of limb segmentation and armature within the Parastenheliidae. In the P3 endopod there is no inner seta on enp 1 in $P$. bulbosa and $P$. oligochaeta and no inner setae on enp 3 in the latter species: only P. bulbosa has one inner seta on ồ enp 3. 
in every conceivable manner" (my translation). Since that time, Apostolov (1968, 1973) has described another form, P. spinosa forma bulgarica, and Wells and Rao (1987) mention that their P. spinosa is most similar to the form described by Sewell (1940) as P. littoralis forma scotti. Thus there appears to be five or six recognizable forms of $P$. spinosa with the result that it has come to be regarded as a highly variable, cosmopolitan species. Whilst there is evidence that some Parastenhelia can exhibit an unusual degree of intra-individual (Mielke 1974) and intra-population (Mielke 1990) variability in setal numbers, it has been shown here that setae can often be very small and/or delicate and could easily have been overlooked in many of the earlier works. Furthermore, there is much recent evidence from cross-breeding experiments, e.g. Glatzel and Königshoff (2005) on Phyllognathopus viguieri (Maupas) and genetic and molecular analyses, e.g. Rocha-Olivares et al. (2001) on Cletocamptus deitersi (Richard) and Staton et al. (2005) on Nannopus palustris Brady, 1880, that species which were previously thought to be cosmopolitan and variable are, in fact, separate species for which the morphological manifestations may be very small and subtle often involving features, such as mouthpart structure and body ornamentation (CastroLongoria et al. 2003), to which many previous descriptions have paid little attention.

With this in mind, I have compared the structures exhibited by $P$. spinosa f. bulbosa from the Scilly Isles with the generally accepted descriptions of $P$. spinosa f. typica and P. spinosa f. littoralis given by Sars (1911), Lang (1948) and Mielke (1974) based on material from north-west Europe. Sars (1911) stated that the only real difference between f. typica and f. littoralis was in the number of setae on the exopod of the female P5 (eight in the former compared to six in the latter) although he did state that in the former seta $\mathrm{V}$ of the caudal ramus was slightly broader than normal at the base and the body and antennule of the latter was slightly more robust than the former. The males of the two forms have the same P5 structure with a three-segmented exopod bearing seven setae. Lang (1948) pointed out that both the number of segments in the female antennule varied between eight and nine even within one individual, and that the extent of the broadening of the base of seta $\mathrm{V}$ varied between individuals. Mielke (1974) described f. typica with three inner setae on exp 3 of P3 and P4 (compared with only two in Sars 1911) but the distal inner seta was a very small, fine, outwardly curving seta that could easily have been missed in the earlier descriptions. Unfortunately in no descriptions are the complete structure of the mouthparts or ornamentation of the body somites and operculum detailed enough to be able to compare with the present material. However, the following are the points of difference between the present material and previous descriptions of $P$. spinosa from northwest Europe on which I have based my opinion that $P$. bulbosa should be regarded as a separate species:

(1) In all female specimens of P. bulbosa, seta IV (the outer principal terminal seta) has a distinctly bulbous basal swelling (Figure 15A) whereas in P. spinosa, seta V, the inner principal terminal seta, has a variable amount of broadening at the base which even in plate LXXVI in Sars (1911) is barely noticeable.

(2) In both sexes of $P$. bulbosa the spines on the terminal segment of both rami of the P1 are short, robust and claw-shaped, whereas in $P$. spinosa they are much more slender and spine-like (cf. Figure. 16A in the present paper with Figure 9B in Mielke 1974).

(3) Consistently, in both sexes of P. bulbosa there is no inner seta on either the proximal or distal segment of the endopod of P2 (setal formula 0:1:021), whereas in all previous descriptions of $P$. spinosa an inner seta is present on both segments (setal formula $1: 1: 121)$.

(4) Similarly, in P. bulbosa the proximal segment of the endopod of P3 in both sexes has no inner seta whereas it is present in all previous descriptions of $P$. spinosa. 
(5) The male of $P$. bulbosa is unique within the genus in that the terminal segment of the sexually dimorphic P3 endopod has an inner seta (endopod setal formula $0: 1: 12+$ apophysis) which is lost in all other species (setal formula 1:1:02+apophysis).

(6) The male of $P$ bulbosa has sexual dimorphism on the P4 enp 3 in that it carries one fewer inner setae (enp. setal formula 1:1:121) than in the female (setal formula 1:1:221). Willey (1935) reported the same sexual dimorphism on P4 endopod for $P$. littoralis f. penicillata. Pallares (1982) reported similar dimorphism on the P4 enp 3 in Parastenhelia minuta Pallares, 1982 but in this species both inner setae are lost in the male. There are no reports of sexual dimorphism on the P4 of any other forms of $P$. spinosa from northwest Europe.

(7) Sars (1911) reports that the the urosomites in f. typica are "densely spinulose at the hind edge both ventrally and laterally" whereas in P. bulbosa (at least from the Scilly Isles) there is only a weak short ventro-lateral row of spinules on the urosomites (Figure 14A-C).

Whilst it is outside the scope of this paper, in my opinion there is a need for a more thorough and much more critical review of $P$. spinosa-like material from around the world than that given in Lang (1948). For instance, Lang (1948) states that "if you compare this [Willey's (1935) description of M. littoralis var. penicillata] and Fischer's (1860) description of Harpacticus spinosus with one another, you will find that the two forms must be without doubt identical" (my translation). However, as stated above, not only is Fischer's description so bad that it is only recognisable as a Parastenhelia by a figure of the P1 but also Willey's description has enough noticeable differences from other descriptions of $P$. spinosa to suggest that it might in fact be a separate species. Willey (1935) noted that the distinctive features of M. littoralis $\mathrm{f}$. penicillata are:

(1) the presence of two spines more coarsely penicillate that in Tisbe on the distal margin to the antennal endopod and on the distal margin of both rami of the P1;

(2) there is the P. bulbosa type sexual dimorphism on the male P4 enp-3;

(3) the male P5 exopod is one-segmented (but with seven setae);

(4) both seta IV and seta V of the caudal ramus are distinctively shaped at the base;

(5) in the endopod of P2-P4 the middle and terminal segments are usually fused.

Lang (1948) dismisses most of these points because he states that Brian (1921) (reference not seen by the present author) found similar spines on the antennal endopod in specimens near Messina in the Mediterranean, without considering the possibility that there might be a group of species with these characteristic spines.

Finally, I have shown that the absence of sexual dimorphism on the endopod of the male P3 (other than the reduction in size of the outer spine in two species) is a characteristic (although probably the plesiomorhic condition) of both Karllangia and Foweya. This reinforces the view of Mielke (1990) that the major autapomorphy for the genus Parastenhelia is the form of sexual dimorphism shown in Figure 20 whereby the outer spine on $\mathrm{P} 3$ enp 3 is transformed into a fused apophysis and there is a reduction in the number of inner setae (to one in P. bulbosa and none in all other species). If this is the case, then both Parastenhelia megarostrum Wells, Hicks and Coull, 1982 and Parastenhelia pyriformis Song, Kim and Chang, 2003 do not belong in Parastenhelia but should be assigned to one or more new genera. 


\section{Acknowledgements}

My thanks to the staff of the Plymouth Marine Laboratory for collecting the specimens; to Dr. Ruth Bottger-Schnack for her efforts to trace material of the type species of Karllangia; to Mr. R. Summers for translation of German texts and to Dr. Rony Huys for useful discussions and suggestions. This work was carried out whilst the author held an Honorary Fellowship at the Plymouth Marine Laboratory.

\section{References}

Apostolov A. 1968. Neue und bemerkenswerte harpacticoide Ruderfußkrebse (Crustacea Copepoda) aus dem Küstengrundwasser Bulgariens. Zoologische Anzeiger 180:395-402.

Apostolov A. 1973. Apport vers l'études d'harpacticoides pontiques habitant les algues marines. Zoologische Anzeiger 191:263-281.

Apostolov A. 1975. Les harpacticoides marins de la Mer Noire. Description de quelques formes nouvelles. Vie et Milieu 25A:165-178.

Bodin P. 1968. Copepodes Harpacticoides marins des substrats meubles des environs de La Rochelle. Recueil des Travaux de la Station Marine d'Endoume 59:279-283.

Bodin P. 1997. Catalogue of the new marine harpacticoid copepods (1997 edition). In: Fiers F, editor. Studiedocumenten van het Koninklijk Belgisch Instituut voor Natuurwetenschappen 89:304 pp.

Bozic B. 1955. Travaux de la station biologique de Roscoff, XXV. Archives de Zoologie Expérimental et Générale, Notes et Revue, 92:1-12.

Castro-Longoria E, Alvarez-Borrego J, Rocha-Olivares A, Gomez S, Kober V. 2003. Power of a multidisciplinary approach: use of morphological, molecular and digital methods in the study of harpacticoid cryptic species. Marine Ecology Progress Series 249:297-303.

Claus C. 1863. Die frei lebenden Copepoden. Leipzig.

Fischer S. 1860. Beiträge zur Kenntniss der Entomostraceen. Abhandlungen der Mathemat-Physikalischen classe der Koeniglich Bayerischen Akademie der Wissenschaften 31:649-682.

Glatzel T, Königshoff D. 2005. Cross-breeding experiments among different populations of the 'cosmopolitan' species Phyllognathopus viguieri (Copepoda, Harpacticoida). Hydrobiologia 534:141-149.

Huys R. 1988. Sexual dimorphism in Aegisthid cephalosomic appendages (Copepoda, Harpacticoida): a reappraisal. Bijdragen tot de Dierkunde 58:114-136.

Huys R, Boxshall GA. 1991. Copepod Evolution. London: The Ray Society. 468 pp.

Huys R, Gee JM, Moore C, Hammond R. 1996. Marine and brackish water harpacticoid copepods., Barnes RSK, Crothers JH, editors. Linnean Society of London, Synopses of the British Fauna (New Series), No 51, $355 \mathrm{pp}$.

Kunz H. 1963. Weitere Harpacticoiden (Crustacea Copepoda) von der süd-westafrikanischen Küste. Zoologische Anzeiger 171:33-51.

Kunz H. 1975. Copepoda Harpacticoidea aus dem litoral des sudlichen Afrika. 1 Teil. Kieler Meeresforschungen 31:179-212.

Lang K. 1934. Marine Harpacticiden von der Campbell-Insel und einigen anderen südlichen Inseln. Lunds. Univ. Årsskr. N. F., Adv. 2. 30(14).

Lang K. 1936. Copepoda, Harpacticoida. In: Nordenskjöld O, editor. Further Zoological Results of the Swedish Antarctic Expedition 1901-1903. Vol III, No.3, Stockholm: P.A. Norstedt and Söner. 68 pp.

Lang K. 1944. Monographie der Harpacticiden (Vorlaufige Mitteilung). (Uppsala: Almqvist and Wiksells Boktryckeri Ab), 39 pp.

Lang K. 1948. Monographie der Harpacticiden. 2 vols. Lund: Håkan Ohlsson’s Bøktryckeri: Stockholm: Nordiska Bøkhandeln. 1682 pp.

Mielke W. 1974. Eulittorale Harpacticoidea (Copepoda) von Spitzbergen. Microfauna des Meeresbodens 37:1-52.

Mielke W. 1990. A Parastenhelia species from Bahĩa Lapataia, Ushuaia, Tierra del Fuego (Argentina). Microfauna Marina 6:157-167.

Mielke W. 1994. Two co-occurring new Karllangia species (Copepoda: Ameiridae) from the Caribbean coast of Costa Rica. Revista de Biologia Tropical 42:141-153.

Monard A. 1935. Ètude sur la fauna des harpacticoides marins de Roscoff. Travaux de la Station Biologique de Roscoff 13:1-88. 
Noodt W. 1964. Copepoda Harpacticoidea aus dem litoral des Roten Meeres. Keiler Meeresforschungen 20:128-154.

Norman AM, Scott T. 1905. Crustacea, Copepoda new to science from Devon and Cornwall. Annals and Magazine of Natural History, Series 7 15:284-300.

Norman AM, Scott T. 1906. The Crustacea of Devon and Cornwall. London: W. Wesley and Son. 232 pp., 24 pl.

Pallares RE. 1982. Copepodos Harpacticoides marinos de Tierra Del Fuego (Argentina). IV. Bahia Thetis. Contribuciõn Cientĩfica del Centro de Investigaciõnde Biologĩa Marina (CICIMA) Buenos Aires, Argentina 186:1-39.

Por FD. 1964. A study of the Levantine and Pontic Harpacticoida (Crustacea, Copepoda). Zoologische Verhandelingen uitgegeven door het Rijksmuseum van Natuurlijke Historie te Leiden 64:1-128.

Rocha-Olivares A, Fleeger JW, Foltz DW. 2001. Decoupling of molecular and morphological evolution in deep lineages of a meiobenthic harpacticoid copepod. Molecular Biology and Evolution 18:1088-1102.

Sars GO. 1911. An account of the Crustacea of Norway. Vol. 5 Copepoda, Harpacticoida, Bergen: Bergen Museum. 449 pp., 180pl.

Sewell RBS. 1940. Copepoda, Harpacticoida. British Museum of Natural History, Scientific Reports of the John Murray Expedition 1933-1934, 7:117-382.

Song SJ, Kim W, Chang C-Y. 2003. A new species of Parastenhelia (Copepoda: Harpacticoida: Parastenheliidae) from Korea. Zoological Science 20:221-228.

Staton JL, Wickliffe LC, Garlitska L, Villanueva SM, Coull BC. 2005. Genetic isolation discovered among previously described sympatric morphs of a meiobenthic copepod. Journal of Crustacean Biology 25:551-557.

Thistle D. 1980. The response of a harpacticoid copepod community to a small-scale natural disturbance. Journal of Marine Research 38:381-395.

Thompson IC, Scott A. 1903. Report on the Copepoda collected by Prof. Herdman at Ceylon in 1902. Report to the Government on Celyon Pearl Oyster Fishery, Gulf of Manaar 1:227-307.

Warwick RM, Dashfield SL, Somerfield PJ. 2006. The integral structure of a benthic infaunal assemblage. Journal of Experimental Marine Biology and Ecology 330:12-18.

Wells JBJ. 1961. Interstitial copepods from the Isles of Scilly. Crustaceana 2:262-274.

Wells JBJ. 1963. Copepoda from the littoral region of the estuary of the River Exe (Devon, England). Crustaceana 5:10-26.

Wells JBJ. 1967. The littoral Copepoda of Inhaca Island, Mozambique. Transactions of the Royal Society of Edinburgh 67:189-358.

Wells JBJ. 1970. The marine flora and fauna of the Isles of Scilly Crustacea: Copepoda: Harpacticoida. Journal of Natural History 4:255-268.

Wells JBJ, Rao GC. 1987. Littoral Harpacticoida (Crustacea: Copepoda) from Andaman and Nicobar Islands. Memoirs of the Zoological Survey of India 16:1-385.

Willen E. 2000. Phylogeny of the Thalestridomorpha Lang, 1944 (Crustacea: Copepoda). Göttingen: Cuvillier Verlag. $233 \mathrm{pp}$.

Willey A. 1935. Harpacticoid Copepoda from Bermuda - Part II. Annals and Magazine of Natural History, Series 10 15:50-100. 